\title{
Beyond the Built Boundary: Could Developing Parts of the Whitebelt Actually Be Beneficial?
}

\author{
By \\ Emelie Rowe \\ B.A. Honours Queen's University \\ A Major Research Paper \\ Presented to Ryerson University \\ In partial fulfillment of the requirements for the degree of \\ Master of Planning \\ In \\ Urban Development
}

Toronto, Ontario, Canada, 2018 


\section{Author's Declaration for Electronic Submission of a MRP}

I hereby declare that I am the sole author of this MRP. This is a true copy of the MRP, including any required final revisions.

I authorize Ryerson University to lend this MRP to other institutions or individuals for the purpose of scholarly research.

I further authorize Ryerson University to reproduce this MRP by photocopying or by other means, in total or in part, at the request of other institutions or individuals for the purpose of scholarly research.

I understand that my MRP may be made electronically available to the public. 


\title{
BEYOND THE BUILT BOUNDARY: COULD DEVELOPING PARTS OF THE WHITEBELT ACTUALLY BE BENEFICIAL?
}

\author{
(C) Emelie Rowe, 2018 \\ Master of Planning \\ In \\ Urban Development \\ Ryerson University
}

\begin{abstract}
The development of rural lands along the urban fringe has remained an ongoing concern for both future growth and the protection of existing farmland. These lands are referred to as the whitebelt. It is a term used within the planning industry to refer to agricultural lands that are neither within a municipal boundary nor the Greenbelt. The lack of clarity surrounding the whitebelt has created a sharp divide in opinions around urban growth and the future of these lands. The purpose of this paper is to better understand opinions of the whitebelt through six stakeholder interviews and a case study. The recommendations presented are based on the responses of the participants to address gaps in the existing policy and how these lands will be treated during future urban expansions and growth. In doing so, the stakeholder interviews established that further research on the topic is essential.
\end{abstract}

Key Words: Whitebelt, Land Use Planning, Urban Expansion, Development, Greenbelt, Land Supply 


\section{Acknowledgements}

I would like to thank my supervisor Ron Keeble for his support and guidance throughout this process. His mentorship and encouragement during the entire year was invaluable.

I would also like to thank the six participants that contributed immensely to my research and the issue of the whitebelt. I thank each one of them for their time and knowledge.

Finally, I would like to thank my family, friends and colleagues for their continued support, kindness and patience throughout the past two years. 
BEYOND THE BUILT BOUNDARY

Dedicated to my Mom and Dad 


\section{Table of Contents}

$1 \quad$ Introduction

$1.1 \quad$ Purpose

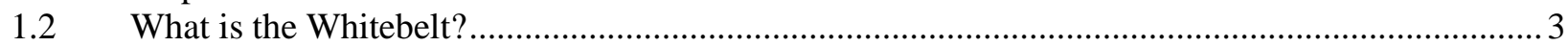

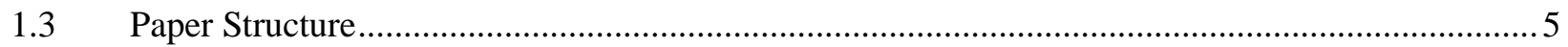

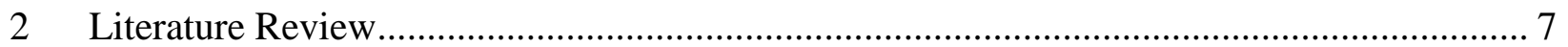

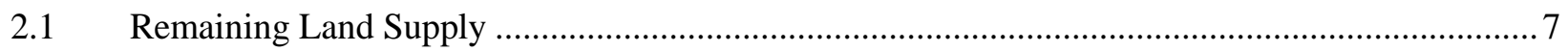

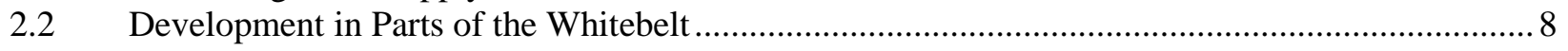

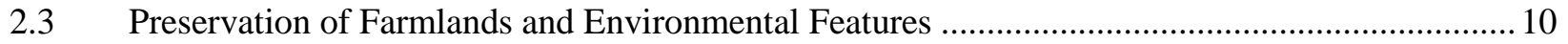

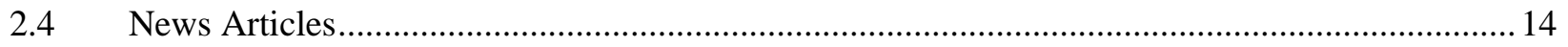

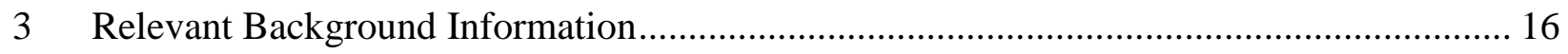

3.1 Visualizing the Whitebelt in the Context of Policy ….............................................................. 16

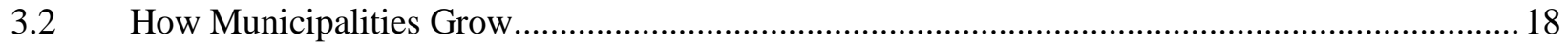

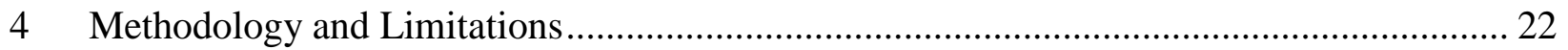

5 Case Study of Caledon's Whitebelt Visioning Exercise .................................................. 24

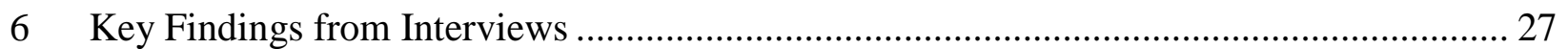

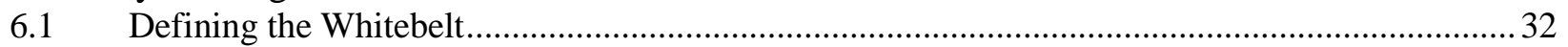

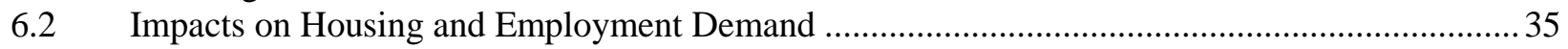

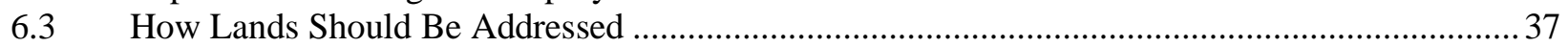

6.4 Environmental Significance and Potential Greenbelt Expansion .............................................. 39

6.5 Commentary on Updated Growth Plan Policies .................................................................... 41

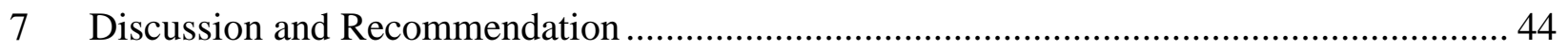

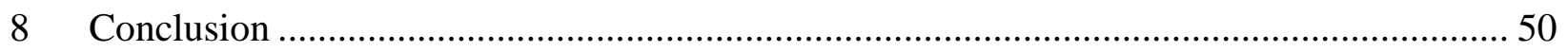

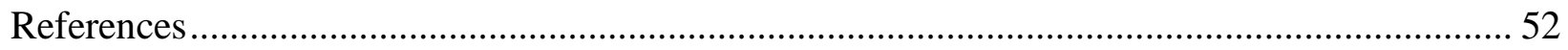

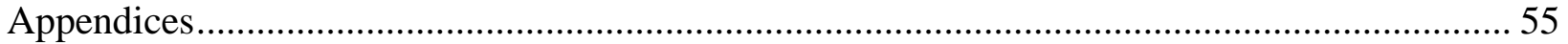

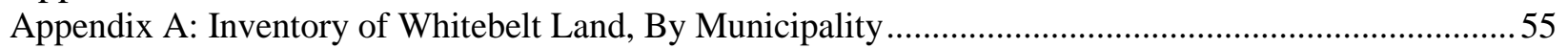

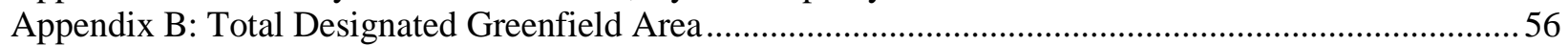

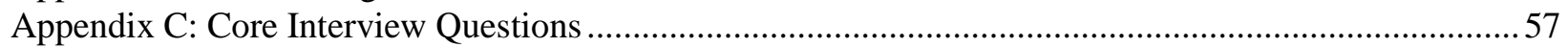




\section{List of Figures}

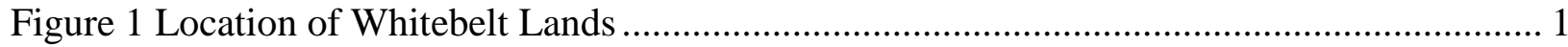

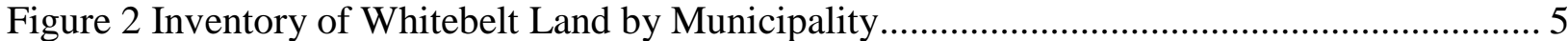

Figure 3 Designated Greenfield Area in Inner Ring Municipalities ..................................... 11

Figure 4 Caledon's Whitebelt Visioning Exercise ....................................................... 24

Figure 5 Illustration of Urban Nodal Densities to the Periphery ........................................... 42

\section{List of Tables}

Table 1 Summary of Important Differences in Opinion from Interviews 33 


\section{Introduction}

\subsection{Purpose}

The development of rural lands along the urban fringe has remained an ongoing concern for both future growth and the protection of existing farmland. These lands are referred to as the whitebelt as seen in Figure 1. They are located between the existing boundaries of the inner ring municipalities and the Greenbelt, an area of land Provincially recognized and protected from development. The whitebelt is located in the regions of Hamilton, Halton, Peel, York and Durham in the Greater Toronto and Hamilton Area (GTHA). The term whitebelt comes largely from the fact that this area is signified in the Provincial Growth Plan for the Greater Golden Horseshoe $(2006,2017)$ as a white or grayish colour.

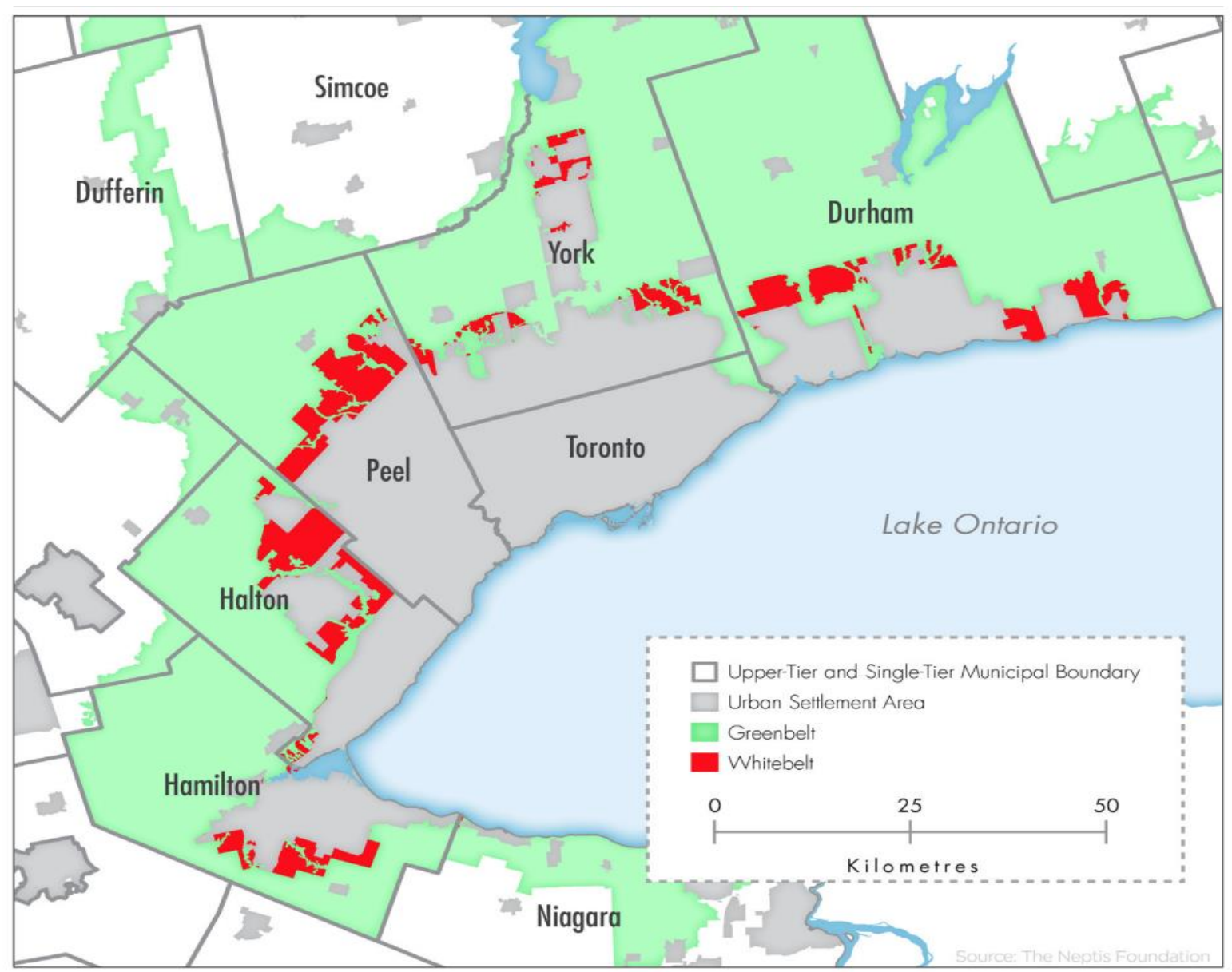

Figure 1 Location of Whitebelt Lands (source: Allen and Campsie, 2013, p. 71) 


\section{BEYOND THE BUILT BOUNDARY}

Neither Growth Plan version has formally recognized the term whitebelt, but designates the lands as Prime Agricultural Areas. The significance of these lands within the whitebelt is in their proximity to the urban boundary and that they have yet to be protected from development through the Greenbelt or potential expansion of it. This has created a divide over how these lands should be viewed and managed in the coming future. Arguably the development industry would like these lands to be made readily available and unprotected against future growth. Others would rather see the lands be maintained and supported for agricultural purposes. It is within the context of these polarizing views where the purpose for this research is embedded.

This paper will attempt to answer the question: What is the current state of professional opinion related to the future development of whitebelt land in the Greater Toronto and Hamilton Area (GTHA) that can better inform policy and how the future of whitebelt lands should be addressed? Secondary questions that will also be addressed throughout the paper are:

- What are the current land supply and housing affordability issues in the GTA, and what role does the development of the whitebelt play in alleviating some of these concerns?

- How can these lands be designated and planned for long term development?

- Conversely, what are the major concerns and implications of developing these lands in the future?

Research was completed through conducting semi-structured interviews with six stakeholders that work within the realm of land use planning. This was supplemented by a review of existing literature and policy. Finally, a case study was undertaken that looked at Caledon's whitebelt visioning exercise as a precedence for other municipalities in the GTHA to begin to see the whitebelt as an opportunity for future growth. It is hoped that this research can add to the 


\section{BEYOND THE BUILT BOUNDARY}

existing, albeit limited literature currently written on the whitebelt. Further the paper can provide a greater commentary on the key issues and policy implications that have made discussions around the development of these lands so contentious.

There are several significant reasons why this topic is worth pursing through research. One of the main reasons is the limited body of research that currently exists regarding the whitebelt. Even more concerning is that the research involves a relatively small number of studies which track remaining developable land as permitted by the Growth Plan and Greenbelt Plan in the context of land supply and housing affordability concerns. Other than what has been written on tracking the land area, only news articles that comment on the future of farmlands and the implications of municipal growth and development activity trends have been found. This gap in literature establishes the need for interviews from targeted participants. Opinions are needed on specific issues related to the future of whitebelt land in Ontario and the relevant planning policies.

Other important issues linked to the topic of the whitebelt is land supply and demand for housing. The development of these lands could potentially have an impact on affordability and rising house prices. Questions around provincial over regulation through hardline designations restricting development have become a central focus for much of the debate around housing affordability. This is especially true in the GTHA. It has also become a central topic in political debate at both the provincial and municipal level.

\subsection{What is the Whitebelt?}

Tomalty and Komorowski (2011) define the whitebelt as a "large but finite band of unprotected

rural and agricultural land" (Tomalty \& Komorowski, 2011, 3). Alternatively, the Neptis Foundation defines the whitebelt as "the lands that lie between the outer edge of the urban 


\section{BEYOND THE BUILT BOUNDARY}

settlement area boundary in the inner ring and the inner boundary of the Greenbelt" (Allen and Campsie, 2013, 70). Although this definition provides a fairly comprehensive starting point in trying to understand the whitebelt there are a few clarifications around boundaries that need to be addressed. The Growth Plan (2017) defines settlement areas as urban and rural areas within municipalities (such as cities, towns, villages and hamlets) that are either built up areas where development is concentrated or lands which have been designated in an official plan for development. The Growth Plan also indicates that the vast majority of growth will be directed to settlement areas that have a delineated built boundary and existing or planned water and wastewater systems. Growth will therefore be limited to settlement areas that do not have delineated built-up areas are not serviced by existing or planned infrastructure or are in the Greenbelt (Growth Plan for the Greater Golden Horseshoe, 2017, 13).

What makes the whitebelt so fascinating is that the actual term has yet to be defined by the Province through planning legislation. It is not formally recognized in any Provincial or municipal policies and it is this key aspect which makes it a fairly contentious part of the planning and development industry. The lack of recognition has allowed for interpretation of policy and makes the future of these lands uncertain.

In 2013, the Neptis Foundation created a land inventory of the whitebelt and calculated the total amount of land within each region and subsequent municipalities. In Figure 2, the regional breakdown of whitebelt lands can be seen. The findings show that the Region of Halton contains the greatest amount of whitebelt land with close to 11,700 hectares. The regions of Durham and Peel are slightly below with 11,500 and 11,300 hectares respectively. With only 5,200 hectares, Hamilton also contains a significant amount of whitebelt lands. 


\section{INVENTORY OF WHITEBELT LANDS, BY MUNICIPALITY (HECTARES) \\ (NEPTIS FOUNDATION, 2013)}

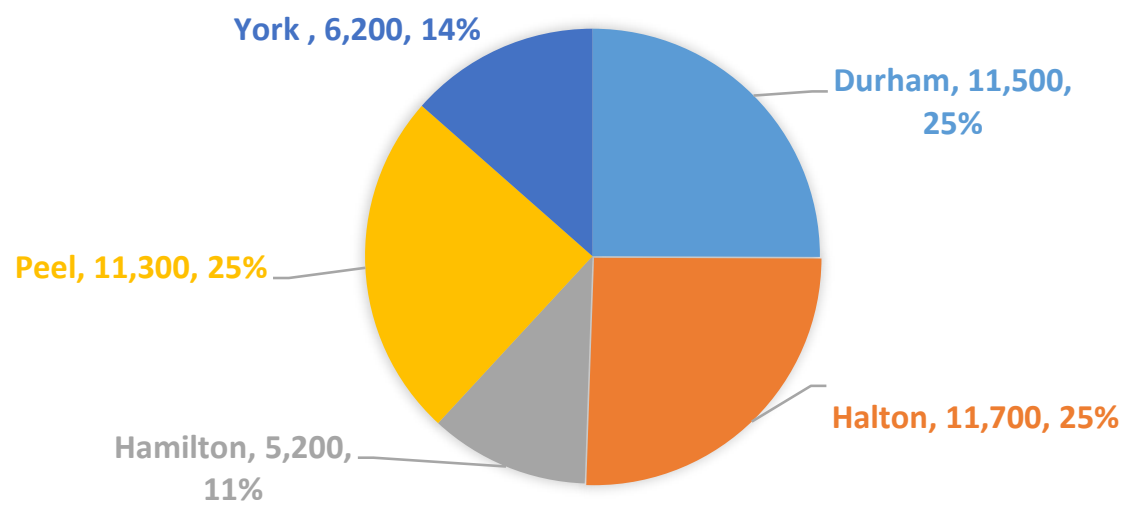

Figure 2 Inventory of Whitebelt Land by Municipality, (Source: Neptis Foundation, 2013) ${ }^{l}$

The amount of land encompassed within the whitebelt provides a necessary starting point for this paper. The only estimated figures that exist in relation to the inventory of whitebelt land are provided from the Neptis Foundation and were completed in 2013. This has important implications when talking about land supply for municipalities seeking to expand their urban growth boundary in order to accommodate new residential and non-residential developments. There are also questions over what considerations were made for the physical form of the lands and whether takeouts were used in the inventory for non-developable land. What can be concluded from this is that there is a need for more detailed statistics on the amount of developable land remaining.

\subsection{Paper Structure}

The organization of this paper will be as follows. First, a literature review will be conducted to provide an overview of what has currently been written on the topic. It will also be shown that

\footnotetext{
${ }^{1}$ See Appendix A for further breakdowns by each Region and their respective municipalities.
} 


\section{BEYOND THE BUILT BOUNDARY}

the literature has been guided by two competing views around the whitebelt. Secondly, an overview of necessary background information and relevant policies will be presented. This will include a review of Settlement Boundary Expansions and how municipalities grow. Thirdly, the research findings from the interviews and case study will be presented. This will attempt to answer the research question and to provide a greater depth of professional knowledge on the whitebelt and the implications to development. Finally, three key recommendations will be presented based on the key findings from the research. The research aims to add meaningfully to the conversation around the whitebelt, long term urban development and related Provincial land use planning. 


\section{BEYOND THE BUILT BOUNDARY}

\section{Literature Review}

As a starting point, there exists little literature that specifically references the term "whitebelt". The term whitebelt is not formally recognized in Provincial planning policies or texts, and has become more or less an overarching term for a vast area within the GTHA that is comprised of primarily farmland. In contrast to the Greenbelt these lands are not protected or defined under any Provincial plans. Much of the literature that relates to the whitebelt comes by way of the debate surrounding supply and demand. The argument is that Provincial planning policies are constraining the supply of developable land thereby creating an affordability crisis.

From this, two competing views can be seen rooted in the literature on the topic of the whitebelt. There are those that see whitebelt land as a future urban reserve for development that should not be over regulated or constrained. On the other side there are those that see it as containing significant environmental features and vital farmland that could be preserved through an expansion of the Greenbelt. These competing views form the basis for this paper to try to better understand the array of opinions that exist on the whitebelt and how these lands might impact the growth of inner ring municipalities over the coming decades. The literature review has been separated into four sections that outline the opposing arguments surrounding the topic.

\subsection{Remaining Land Supply}

To date few studies have been created to track the land within the whitebelt in order to provide a context for the future of the lands in relation to urban expansion. In a study undertaken by Allen and Campsie (2013) for the Neptis Foundation, the authors questioned whether or not the policies and minimum density targets provided within the Growth Plan (2006) had compromised the actual vision and intent of the Provincial plans. It was based on land supply and allocated land 


\section{BEYOND THE BUILT BOUNDARY}

for growth, including greenfields and the whitebelt, and looked at how municipalities were adopting certain intensification and density target components of the Growth Plan. In the report the whitebelt area was tracked by calculating the land area that each region and subsequent municipality had of land not within a delineated built-up boundary or protected and designated within a plan. At the time it was found that the whitebelt consisted of close to 46,000 hectares of land (Allen and Campsie, 2013). However, a report by Tomalty and Komorowski (2011) shows there were approximately 58,696 hectares of land that made up the whitebelt (7). Despite being two years apart, some possible reasons for the discrepancy in numbers can be seen. How the land area is calculated and whether or not calculations were based on net developable, take outs, or the entire area can have a major impact. Nonetheless, many argue that the amount of land is more than enough to sustain growth over time and that there is no need to put pressure on municipalities to develop quickly.

\subsection{Development in Parts of the Whitebelt}

On the development side of the argument much of the literature argues for timely expansion into areas of the whitebelt in order to provide for market demand through an increase in serviceable land. In the Advisory Panel Report led by David Crombie entitled Planning for Health, Prosperity and Growth in the Greater Golden Horseshoe (2015) it was reported that "the development sector has generally assumed that the lands below the Greenbelt will eventually be urbanized, and most of these lands have now been purchased or optioned by investors" (73). The vested interest in these lands by the development industry for growth in the region has been one of the benchmark opinions in the vigorous debate. 


\section{BEYOND THE BUILT BOUNDARY}

Much of the literature that comes from this is based on land supply and housing prices. In their report Countering Myths about Rising Ground-Related Housing Prices in the GTA, Amborski and Clayton (2017) seek to debunk the myths that have come to surround much of the discussion related to the rising housing price problems that are not objective or engrained in data-based research. Their approach is rooted in market based research and realities which show the need for greater land supply that is serviced for ground-related housing. When it comes to the topic of the whitebelt, it is referenced in regard to the myth that "developers want to pave over the Greenbelt with large, single-detached houses on large lots" (Amborski and Clayton, 2017, 12). In reality the development industry is much more concerned with the potential impacts of the Growth Plan on the future of whitebelt lands since these lands are in the path of future development before Greenbelt lands (Amborski and Clayton, 2017, 12). The authors also provide clarification on the idea that developers are building large lot, single-detached homes, adding to greater 'sprawl' across the GTHA. Amborski and Clayton (2017) point to the decline in the built-up expansion due to smaller lot developments since 1986. (12). Brad Graham, an economist, was quoted in 2015 saying that 'I'm not advocating for paving over the whitebelt. I'm stating don't close off the possibility for future development over the next century [for] the case can be made today that a hard urban boundary is not the way to go because it will choke off supply and raise land prices" (Daniel, 2015). Graham also points to the changing demographics of the GTHA. With the influx of migrant families and aging baby boomers, as he questions "What's that going to do to our housing index?” (Daniel, 2015).

The entire GTHA region is experiencing a major "shortfall in the provision of serviced, permit-ready land for grade-related housing (singles, semis and townhouses) and it is argued that "this shortage is one of the primary contributing factors to the increase in housing prices in the 
GTHA” (Given et al., 2017, 6). In a report presented by Malone Given Parsons (2017) it is argued that even the timing of development for designated greenfield lands has been increasing. This is due largely to the increased requirements for planning, environmental and technical studies, and the approvals needed. The report argues that "the delay in developing significant portions of the Designated Greenfield Area have become the critical constraint for delivering new housing to keep pace with the Province's 2031 planning horizon" (Given et al., 2017, 6). This delay in providing a stable supply of housing is ultimately one of the major issues surrounding the development of the whitebelt.

\subsection{Preservation of Farmlands and Environmental Features}

On the other side of the debate, the existing research and literature argues for the importance of maintaining the whitebelt land as rural and agricultural areas. Some even call for the expansion of the Greenbelt into the area for its protection. In a report written for the David Suzuki Foundation, Wilson (2013) examines the necessity of protecting the farmland and agricultural areas that make up the whitebelt by arguing that development of these areas is not appropriate and would result in a loss of significant natural capital. The purpose of the report was to argue that these lands should not be designated for future growth but rather protected for environmental conservation.

Yet, there has been pressure to expand development into areas of the Greenbelt through

releasing land from within. In their paper, Tomalty and Komorowski (2011) argue that there should be no pressure, in principle, for urban expansion into the Greenbelt in the foreseeable future. If the Growth Plan's projections hold true, and if expansion of the inner-ring municipalities goes as prescribed by the plan, then "the supply of land in the whitebelt should suffice to accommodate 


\section{BEYOND THE BUILT BOUNDARY}

development for several generations" (Tomalty \& Komorowski, 2011, 2). In contrast, Malone Given Parsons found that the answer is not as simple as that. Extensive analysis was undertaken to determine that there is "only about 17,200 hectares of 'vacant' residential designated greenfield land that has not been 'committed', representing only $5.6 \%$ of the total 292,000 hectares of Settlement Area lands in the GTHA" (Given et al., 2017, 3). Figure 3 provides the exact breakdown and summary of the findings from the report.

\section{DESIGNATED GREENFIELD AREA BREAKDOWN}

(MALONE GIVEN PARSONS, 2017)

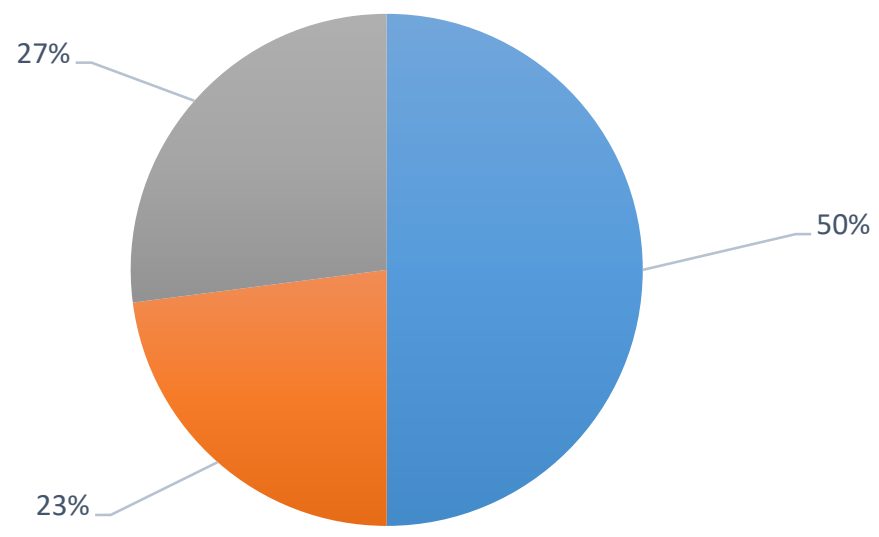

- Total Community Area Greenfield

Committed Community Area

- Vacant Area

Figure 3 Designated Greenfield Area in Inner Ring Municipalities (source: Given et al., 2017)²

The key point from the report is how and where urbanization should proceed in the whitebelt and how it will impact future expansion efforts, development patterns and the agricultural and ecological systems found there. In the Advisory Panel Report led by David Crombie for the Province of Ontario, the recommendations for the future of whitebelt lands point to strengthening the protection of the area as vital agricultural lands, that contain significant water resources and natural heritage systems (Crombie et al., 2015, 73). Regardless, it was found that an issue taken

\footnotetext{
${ }^{2}$ See Appendix B for full calculations.
} 


\section{BEYOND THE BUILT BOUNDARY}

with the findings was that "additional policy direction is needed on the so-called 'whitebelt' lands located between the Greenbelt and urban boundaries in the inner ring" (Crombie et al., 2015, 37).

In their report, Allen and Campsie (2013) argued that, "since the Growth Plan and Greenbelt Plan were established, representatives of the development industry have argued that the Growth Plan has constrained the land supply and forced up housing costs" (2). During the time that the report was written there were an estimated 107,100 hectares set aside to accommodate forecasted population growth. It was argued that should densities increase, the land supply would last even longer and have implications on the fate of the whitebelt (Allen and Campsie, 2013, 2). Yet, it was argued that the Growth Plan, in its initial intent, was not fully being implemented by municipalities and the density targets set out were not being achieved. The impact was therefore on the amount of agricultural and rural lands that were meant to be protected- the whitebelt in the inner ring and rural areas within the outer ring that were instead being developed. Ultimately their findings supported the "conclusion that more than simply land use regulation is needed to manage growth" (Allen and Campsie, 2013, v). Other components which include fiscal tools and revisions to development act as a barrier to compact development.

These findings, although slightly outdated, are still relevant today with regards to land supply and the housing market. Doyle (2017) argues that the development industry has been mounting a campaign to undermine the Growth Plan and Greenbelt Plan. They suggest that the policies are to blame for the increase in housing prices in the GTHA and the supply of land for ground related housing. In defense of this Doyle (2017) maintains that "low density urban sprawl continues to have devastating and debilitating short and long-term negative impacts on our health, environment, resources and economy. The evidence clearly provides the case for why the Plans have to be strengthened and enhanced and why our resolve to implement them needs to be even 


\section{BEYOND THE BUILT BOUNDARY}

more determined" (4). The argument is that there is not actually a land supply issue and that this belief has been more or less crafted by much of the development industry. It should be seen that "these claims have led to a concerted effort by elements of the greenfield development sector to advocate for substantial expansion of our urban boundaries - including identifying the entire "whitebelt" as a "future urban reserve" while also advocating for continued and increased leapfrogging of the Greenbelt - in order to urbanize more land for these housing types" (Doyle, 2017, $15)$.

One of the main arguments for preserving the agricultural lands is that municipalities, within their delineated built-up boundaries, contain enough greenfield land that can accommodate future growth without having to expand into agricultural lands. Yet, as aforementioned the findings from Given et al., (2017) show that, "of the 'vacant' 17,200 hectares of Designated Greenfield lands, the majority are currently mid-way through a development process to implement the 2006 Growth Plan, relying on [a] density target of 50 residents and jobs per hectare". Therefore, there is a significant delay in developing portions of the greenfields. This has become a critical constraint for delivering new housing and jobs to keep pace with the 2031 projections and now the 2041 planning horizon (Givens, et al., 2017). Timing for development is being pushed back. With the increased time it takes for planning approvals, and the new Ontario Municipal Board (OMB) reform, this timeline will most likely be delayed further. Thus, if these greenfield areas are developed with the original intensification goals of 50 persons and jobs per hectare, the density is no longer satisfactory under the updated Growth Plan. This is to say that when the growth to be assumed for 2041 is taken into consideration, the need for some serviced greenfield land will be necessary. When this time comes, the land looked upon will come from within the whitebelt. 


\subsection{News Articles}

Aside from research publications and reports, a number of news articles have been published around contentious development applications and projects that are beginning to move into rural areas on municipal boundaries. These news stories also highlight the impact that opinion has on the topic and the bias that may be woven into the story. In an article published in 2010 by the Newmarket Era that reported on a committee of a whole decision, the approval of an urban boundary expansion area in Vaughan created a stir between the development industry and the environmental coalition Sustainable Vaughan ("Vaughan White Belt Plan in Works", 2010). Some of the land was owned at the time by large developers in the community, including Silvio DeGasperis, who maintained that development on the newly released whitebelt lands would be developed to include a range of housing types, schools, parks, and commercial buildings. DeGasperis was quoted as saying "it is our intention to continue to contribute to the evolution of the City of Vaughan as a complete community". He claimed he would like to see the development of the lands occur in a timely manner but "there are constraints to the provision of water and sewer and transposition that the city and the region will need to address" prior to the development of the lands" ("Vaughan White Belt Plan in Works", 2010). It was reported that many who attended the meeting were against the expansion and called for a hold on any new development to allow for further discussion. Councilor Tony Carella was quoted asking, "What's the point of having the plan? Why should we have any planning at all? This is an abdication of our responsibility" with regards to the approval that was called at the time irresponsible ("Vaughan White Belt Plan in Works", 2010).

On February 28, 2018, Nicola Saminather and Matt Scuffham wrote an article Toronto's Housing Supply Challenge and The Growth Plan Paradox in the Financial Post, that reiterates the 


\section{BEYOND THE BUILT BOUNDARY}

housing supply problem in Toronto but questions why the development or construction industry has not yet caught up. The authors argue that the reason, in part, lies within the disconnect between the major goals of the growth plan for multi-family units and higher density targets, and market demands for low density, detached homes. With the new updates to the plan, developers say the growth plan created both a "demand-supply mismatch and added a layer of new municipal regulations" (Saminather \& Scuffham, 2018). Of course the issue is more complex than just the growth plan's vision. Developers have also had a hand in staggering development and increasing supply through "land banking" delaying projects in anticipation that prices will rise further (Saminather \& Scuffham, 2018).

The importance of looking at news articles is the opinions and bias that can be seen. In literature, the topic of the whitebelt is most evident in newspaper articles and headlines that talk about growth and the crisis of housing affordability and demand. While articles provide a good level of understanding about the context of the whitebelt, there is very little clarity provided as to what the whitebelt truly represents. This highlights the need for greater studies and research into the issue. 


\section{Relevant Background Information}

\subsection{Visualizing the Whitebelt in the Context of Policy}

To provide a framework in understanding what and how the whitebelt has formed an examination of Provincial policies and plans is necessary. What is important to note is that the actual term whitebelt is not documented in Provincial policy and guiding legislation. Rather these lands are referenced as being mainly Prime Agricultural Areas and are largely related to settlement boundary expansions. In 2006, the province of Ontario under Dalton McGuinty's majority Liberal Government created the Growth Plan for the Greater Golden Horseshoe as a way to guide where and how growth should occur in the region up until 2031 through greater intensification and compact development (White, 2009). The purpose was to create a regional growth management strategy to make use of the limited land supply and create more complete, connected and efficient communities across and within the Greater Golden Horseshoe (GGH). At the same time, the government also created three other key regional initiatives, the Greenbelt Plan (2006), the Oak Ridges Moraine Conservation Plan (2006) and the Niagara Escarpment Plan (1990). These three plans intended to prevent development and protect environmentally significant lands. The Growth Plan was born out of the vision and policies of smart growth, which was originally conceived as a reaction to the undesirable features of continuing growth through suburban sprawl, including 'leapfrog' expansion of low-density development and large scale conversion of open space and environmentally sensitive land (Downs, 2005, 367). The term smart growth has become almost an ambiguous term that planners and municipalities use interchangeably to promote and advocate for many different forms of development. Nevertheless, common principles of smart growth can be seen in the use of urban growth boundaries to limit outward expansion of new development, increasing residential densities, advocating for more mixed use development, the use of impact 


\section{BEYOND THE BUILT BOUNDARY}

fees, emphasizing public transit, and revitalizing existing neighbourhoods (Downs, 2015). A link can be drawn between these smart growth ideals and the original 2006 Growth Plan that focused on increasing density and intensification targets within existing urban boundaries as a means to mitigate sprawl.

When the Growth Plan was first enacted, it was argued that the ambitions of the plan were "historically unprecedented [and that] none of the earlier plans attempted to do so much" (White, 2007, 5). The original intent of the plan was to "guide decisions on a wide range of issuestransportation, infrastructure planning, land use planning, urban form, housing, natural heritage and resource protection- in the interest of promoting economic prosperity" (Growth Plan for the Greater Golden Horseshoe, 2006, 6). The vision for the plan was projected to 2031 in the hopes of creating a more sustainable, integrated and connected region with productive rural and urban centres, with a focus on greater intensification in built-up areas. It was intended that by the year 2015 and for each year thereafter, a minimum of 40 percent of all residential development would be within built-up areas of single- and upper- tier municipalities. At the time designated Greenfield Areas were to have a minimum density target of no less than 50 people and jobs combined per hectare.

The updated Growth Plan (2017) calls for the vast majority of growth to be directed to Settlement Areas that have a delineated built boundary, have existing or planned servicing structures and can support the vision of complete communities. The Provincial Policy Statement (PPS) states that "development shall be appropriate to the infrastructure which is planned or available, and avoid the need for the unjustified and/or uneconomical expansion of this infrastructure" (PPS, 2014, 10). In contrast, growth will be limited to areas that are not delineated built-up areas, not serviced or are within the Greenbelt boundary. By the year 2031, and for each 


\section{BEYOND THE BUILT BOUNDARY}

year thereafter, a minimum target of 60 percent of all residential development within upper- or single-tier municipalities will be within delineated built-up areas. A minimum of 50 percent residential intensification will be called for by the time the next municipal comprehensive review is approved and in effect, and each year until 2031. Designated greenfields have been slated for new development opportunities that will be planned and designed in a manner to support and ensure active transportation, sustainable transit services, and complete communities. The updated greenfield density target is now 80 people and jobs per hectare.

The purpose of providing a policy review is to show how planning in the GGH has been conducted to better understand the vision that guides the policy direction through targets and intensification goals. It is within this realm of policy where the question of what the whitebelt is and how it should be addressed lingers.

\subsection{How Municipalities Grow}

Providing an overview of how municipalities expand their boundaries is an important aspect of the discussion and the development of lands not within existing urban boundaries, settlement areas or designated greenfields. In December 2017 the province of Ontario drafted the Proposed Methodology for Land Needs Assessment for the Greater Golden Horseshoe (2017), as a means to ensure that growth was taking place in a timely manner and that municipalities were not expanding too rapidly. In it, it is argued that "it is important to optimize the use of the existing urban land supply as well as the existing building and housing stock in order to avoid over designating land for urban development” (MAH, 2017, 2). In order for municipalities to expand their boundary, they are required to "first demonstrate that they are optimizing existing urban land, 


\section{BEYOND THE BUILT BOUNDARY}

infrastructure and public service facilities, before they expand the urban area to accommodate population and employment growth" (MAH, 2017, 2).

The Growth Plan (2017) provides strategic and strict direction for how Settlement Area Boundary Expansions may be implemented through municipal official plans and a Municipal Comprehensive Review (MCR). It should be noted that the Growth Plan (2017) defines a Settlement Area as urban and rural areas within municipalities that are built-up, such as cities, towns, villages and hamlets (Growth Plan for the Greater Golden Horseshoe, 2017, 83). This where development is concentrated and includes lands that have been designated in an official plan for development. A MCR is the process of comprehensively applying the policies of the Growth Plan at both the upper- and single-tier municipal level and involves integrated analysis on a variety of matters of which land needs is just one component (MAH, 2017, 3). A MCR must demonstrate that the minimum intensification and density targets of the Growth Plan (2017) and land needs assessment together do not provide sufficient opportunities to accommodate the forecasted growth until the planned horizon of 2041. The feasibility of expansion- including but not limited to existing or planned infrastructure and services, water and wastewater master plan, fiscal impact analysis, storm water analysis, watershed planning, and an agricultural impact assessment- must all be completed and worked into the MCR to prove that expansion is necessary and can be supported by the municipality (Growth Plan for the Greater Golden Horseshoe, 2017, 27). The purpose is to ensure that lands are not being over designated and that growth will occur in a timely manner. This is to ensure the longevity of resources and the creation of smart, transit-oriented, complete communities. The results of the land needs assessment will be a total quantum of land needed, or excess land, determined by and at the upper- and single- tier municipal level. It will provide a critical input into the MCR process through which the appropriate locations for proposed 


\section{BEYOND THE BUILT BOUNDARY}

boundary expansions, identification of excess lands- which includes potential whitebelt land, or possible conversions of employment areas to non-employment areas- will be determined (MAH, 2017, 105).

Policies have been laid out in the Growth Plan (2017) that focus strictly on prime agricultural areas and settlement area boundary expansions and directly relates to the development of the whitebelt. Small portions of forecasted growth may occur in these rural areas, which must be accounted for in the land needs assessment and the MCR. Policies currently recognize that development should be avoided through reasonable alternatives. Yet, it must be acknowledged that settlement boundary expansions often come at a cost. The loss of land that is seen as prime developable and "raw" land contains significant natural resources, ecosystems and habitats. This highlights again the intrinsic and complex nature of the whitebelt topic. Development will occur at the cost of the natural environment. Also, without ensuring growth for both housing and employment demands, the market could be severely impacted as well. What follows is an overview of the methodology and limitations of the research that was conducted and then an analysis of the findings to better understand the whitebelt and provide potential policy recommendation for these lands.

Having planned or existing servicing and infrastructure is a substantial aspect of where municipalities will expand and regions will focus growth. Aside from the cost, other factors include good planning and whether expanding into certain areas are more appropriate than others. The expansion will require the municipality to carry out a comprehensive review and demonstrate that growth cannot be accommodated through intensification or in existing designated greenfield areas (Allen and Campsie, 2013). When it comes to servicing the region is responsible for the development and construction of new major highways, roads, and trunk sewers, that must be 


\section{BEYOND THE BUILT BOUNDARY}

approved before expansion of municipal boundaries can really be accommodated for. This is to say that expansion is a long term and complicated process. It requires comprehensive reviews, studies and budgeting by the regions and municipalities to show that existing greenfield land is not adequate to allow for the development of lands outside of current boundaries. 


\section{Methodology and Limitations}

Research was completed using a mixed-method approach that combined a literature review, semi-structured interviews, and a case study analysis. The primary method to determine key findings was through the interview process which was conducted with six different stakeholders who had a high level of familiarity with the whitebelt and knowledge of Ontario's land use planning regime. This was supplemented by a case study of Caledon's Whitebelt Visioning exercise in order to better understand how municipalities recognize the whitebelt as both a short and long term land reserve.

Semi-structured interviews were conducted with six stakeholders as a pre-test to determine the necessity of a future study on the topic of the whitebelt. The small sample size allowed for a more refined interview process that was needed to better encapsulate the issue. Participants were from both the public and private sector, within the realm of municipal/regional planning, academic research, environmental conservation, and/or the development industry. The criteria used for selecting the participants was based on their capability to speak to and provide an opinion on the issue. Participants were contacted for an interview because they are experts in their field and were seen as having the ability to provide a more refined understanding of the topic. All participants were asked the same core questions. The questions were created to be broad enough to elicit an array of opinions that would contribute to the research in a meaningful way ${ }^{3}$. Questions were based on the current literature and competing views on the topic of the whitebelt and the subsequent future development of parts of the area.

\footnotetext{
${ }^{3}$ See Appendix $\mathrm{C}$ for list of core questions used in guiding the interviews. It should be noted that these questions were intended to guide conversation and that other questions were asked specific to each participant.
} 


\section{BEYOND THE BUILT BOUNDARY}

The intent of the research is to address the gap in policy and literature that exist on the topic. A limitation to this study is the relatively small number of participants interviewed that would yield only a selection of perspectives. Despite this, the small sample size was used as a pretest to scope and refine the interview methodology and line of inquiry in support of a larger study. A small sample size is needed to better capture the issue when there is wide variance in opinion on a subject with little existing literature to provide greater evidence. It was found that conducting interviews with six stakeholders would provide the greatest insight into the topic since there exists very little data and published research that talks directly to the whitebelt. Representing various perspectives through individual lenses the participants presented opinions based on a variety of influences and familiarities. Despite the limitations, this research provides a preliminary approach to determine the need for a greater study and investigation into the issues surrounding the whitebelt. 


\section{Case Study of Caledon's Whitebelt Visioning Exercise}

Based on the preparation of the GTA West Corridor Study, which was initiated to look at the potential of extending highway 400 to the existing Highway 401/407 interchange area, in 2015 the Town of Caledon directed planning staff to initiate a visioning exercise of the whitebelt lands. At the time the Town of Caledon Mayor Allen Thompson argued that "this exercise will help to build a truly Caledon plan, designed by our community" and would hopefully help to provide residents with a better understanding of the planning process and local policy impacts ("Whitebelt Visioning Exercise", n.d.). Figure 4 provides a context for the exercise and the location of whitebelt land in the municipality.

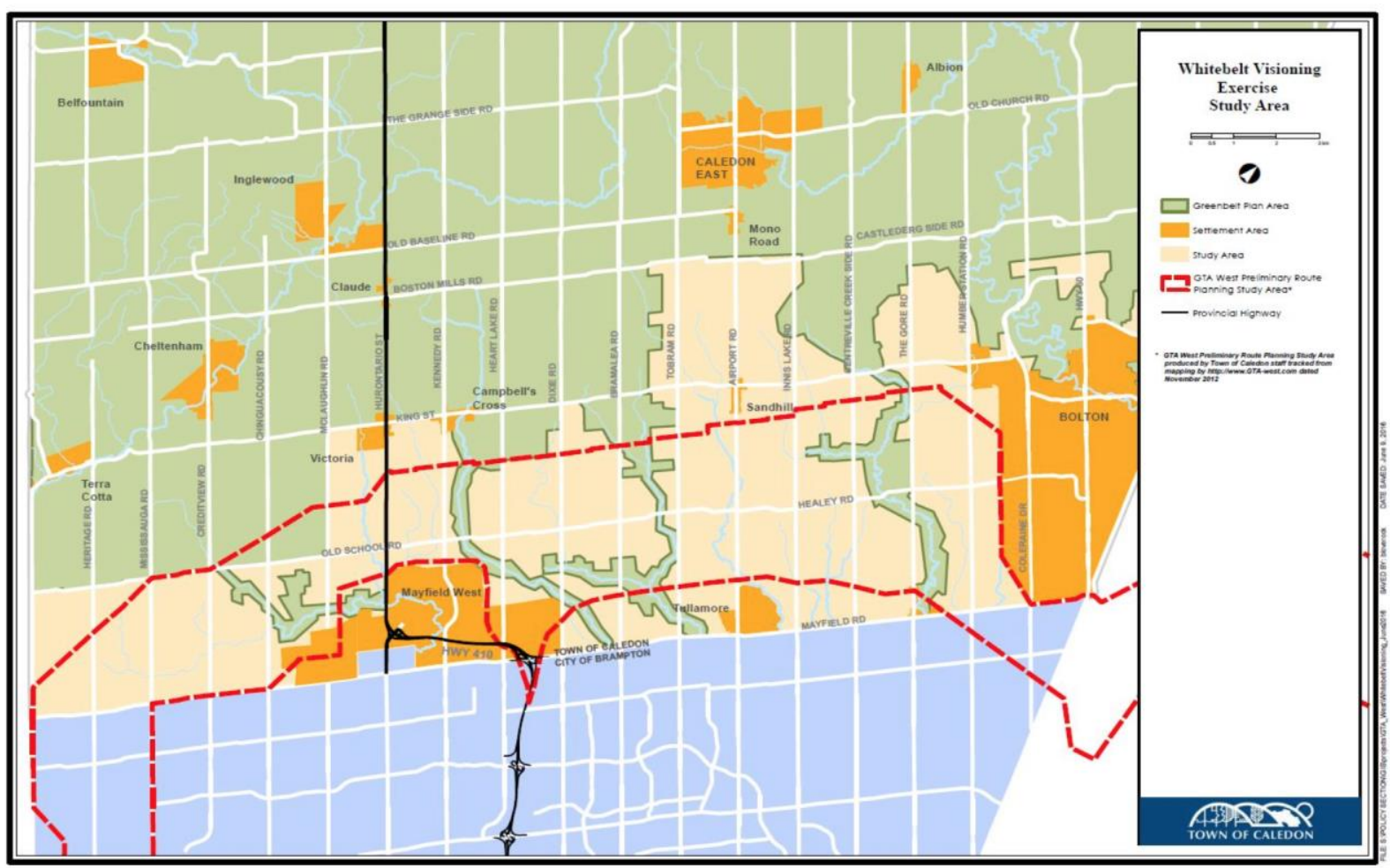

Figure 4 Caledon's Whitebelt Visioning Exercise (Source: Town of Caledon, 2015)

The whitebelt encompasses $105 \mathrm{sq} / \mathrm{km}$, or $15 \%$, of Caledon's land, which is defined as an area where urban development may be permitted ("Whitebelt Visioning Exercise", n.d.). The entire land area of the town of Caledon is $687 \mathrm{sq} / \mathrm{km}$, which is larger than the Toronto area; 
however, $85 \%$ of the Town is subject to all four Provincial policies- the Niagara Escarpment Plan, Oak Ridge's Moraine Conservation Plan, Greenbelt Plan and Growth Plan ("Whitebelt Visioning Exercise", n.d.). This makes the planning framework for Caledon a highly layered and fairly complex process to ensure conformity to all four plans. The visioning exercise was not only premised in the GTA West Corridor Study, but also on the fact that the projected population for Caledon at the time meant the potential of 525,000 people and jobs coming into the Town based on the 10,500 hectares of whitebelt land ("Whitebelt Visioning Exercise, n.d.). It was this projection that highlighted the necessity of the Town to take the lead in the planning of a study that would have a significant impact on the preparation of long term land use and infrastructure plans. It was argued that the potential new highway would provide a considerable opportunity for the Town to capitalize on the location of a major 400 series highway, which would support the development of new employment opportunities for Caledon and the entire region.

However, on February 9, 2018 the province of Ontario presented a news release detailing that "Ontario has accepted an expert advisory panel's recommendation that a proposed highway in the GTA West corridor is not the best way to address the changing transportation needs", thereby cancelling the study (Ministry of Transportation, 2018). This decision has ultimately disrupted the work that has been done up until this point on the visioning exercise; however, it is important to look at the lessons that can potentially be learned from the process.

The Caledon Whitebelt Visioning Exercise is significant in that it represents the first time a municipality not only directly addressed the whitebelt, but recognized the lands as a vital area for future growth and development. Despite the GTA West Corridor Study being cancelled, Caledon created a strong precedent for how municipalities should plan for the future. The municipality recognized the need to allow residents and stakeholders to have a role in the planning 


\section{BEYOND THE BUILT BOUNDARY}

process and not have growth take place through development pressures. This study also acknowledged the importance of employment lands for the future growth of the municipality and the opportunity to attract jobs and investment. Thus, what started as a visioning plan to scope out where potential employment lands might go if the highway was approved, soon turned into the visioning of a complete community. It became fairly evident that the development of whitebelt lands in Caledon would require an overall community vision, guiding future growth of undeveloped lands in the Town.

Although the GTA Corridor West Study has been cancelled, it should be seen that the efforts of Caledon was to try and look beyond the need for development short term, and see the significance of having a plan in place for when and if major infrastructure and servicing were to be built. It also highlighted the importance of the provision of major infrastructure to service these lands in a cost effective manner. The visioning exercise was a way in which the municipality could take control of the planning process through strategic initiatives aimed at future land development. 


\section{Key Findings from Interviews}

The following section will outline the key findings and elaborations provided by the respondents. The findings are presented based on key themes that emerged from the questions and organized according to the six participant's professional opinions and affiliations. Table 1 summarizes the important differences in responses and the meaning that each of the participants attached to the whitebelt.

\section{Table 1: Summary of Important Differences in Opinion from Interviews}

\section{Participant Response/Opinion ${ }^{4}$}

(Organized by Profession)

\section{Topic One: Defining the Whitebelt}

\begin{tabular}{|l|ll|}
\hline Academic/Research & - $\begin{array}{l}\text { Contains lands that should be held for urban expansion in order to } \\
\text { accommodate growth and development. } \\
\text { These lands will be highly important in the next 20-40 years. }\end{array}$ & - \\
\hline Regional Planning & $\begin{array}{l}\text { Rural lands that are currently not designated within the urban boundary and } \\
\text { the Greenbelt. }\end{array}$ \\
\hline Municipal Planning & - $\begin{array}{l}\text { Whitebelt lands are also not within other Provincial planning regimes, which } \\
\text { mairly desirable for developers to purchase and hold. }\end{array}$ \\
\hline $\begin{array}{l}\text { up of rural and agricultural lands, primarily used for farmland. } \\
\text { Development of whitebelt lands and settlement boundary expansions can be } \\
\text { seen as a political priority that allows the city and community at large to take } \\
\text { control of planning in their area and have a say in how development should } \\
\text { form. This can be done through various planning consultations and public } \\
\text { presentations. }\end{array}$ \\
\hline Development Industry & $\begin{array}{l}\text { Hard to define because the province has not actually delineated it making it } \\
\text { more or less an undefined feature. People in the planning industry have an } \\
\text { idea of it and know where it is but it is something that the Province should } \\
\text { define in policy. } \\
\text { Without a formal definition, the term has been subject to interpretation. }\end{array}$ \\
\hline
\end{tabular}

\footnotetext{
${ }^{4}$ The responses provided are notes from the interviews. What is being presented is not a collective opinion of each of the participants or their profession. Not all interviewees had a response to each of the question. Opinions have been presented based on theme not by the questions asked.
} 


\begin{tabular}{|c|c|}
\hline & $\begin{array}{l}\text { - The whitebelt should be seen as a safety valve between municipal boundaries } \\
\text { and the edge of the Greenbelt. The whitebelt is a long term urban reserve, } \\
\text { whereby the key here is long term. }\end{array}$ \\
\hline Conservation & $\begin{array}{l}\text { - The Growth Plan provides a clear understanding as to what the whitebelt is } \\
\text { through the designation of Prime Agricultural Areas. Policies for how these } \\
\text { lands should be used are provided for in the designation. }\end{array}$ \\
\hline $\begin{array}{l}\text { Environmental } \\
\text { Organization }\end{array}$ & $\begin{array}{l}\text { - Provides an important buffer area between urban areas and the natural } \\
\text { heritage and agricultural systems of the Greenbelt. } \\
\text { - Contains important components of the regional agricultural and natural } \\
\text { heritage system that stores vast quantities of carbon, helps to reduce flooding, } \\
\text { and provides valuable services that benefit the urban communities of the } \\
\text { GTHA. } \\
\text { - These lands can be used to grow the agriculture support network that can feed } \\
\text { and employ the GTHA's and even Ontario' growing population. }\end{array}$ \\
\hline \multicolumn{2}{|c|}{ Topic Two: Impacts on Housing and Employment Demand } \\
\hline Academic/Research & $\begin{array}{l}\text { - Planners seem to be more concerned with meeting policy than 'numbers' and } \\
\text { because of this there seems to be very little incentive for planners to be } \\
\text { concerned with the economy and housing. } \\
\text { The planning system is one of the reasons in why house prices have gone up } \\
\text { as well as the minimal amount of serviced land available for development. } \\
\text { Whitebelt lands are highly important for future growth and these lands should } \\
\text { be available for development if needed. } \\
\text { Disconnect between Growth Plan and reality in that there is a focus on putting } \\
\text { greater intensification on the urban fringe where there is little infrastructure } \\
\text { and services including transit to support this. Need to think critically about } \\
\text { the planning policies of Provincial plans and the reality of development on the } \\
\text { ground. }\end{array}$ \\
\hline Regional Planning & $\begin{array}{l}\text { - Proper planning for these lands is important in both the short- and long- term } \\
\text { in order to accommodate projected regional growth. } \\
\text { Regional interests can be found in the servicing of the lands for long term } \\
\text { development. This is especially true in municipalities where growth will be } \\
\text { more prevalent than in others where they are almost completely grown out. }\end{array}$ \\
\hline Municipal Planning & $\begin{array}{l}\text { - Municipalities need to be able to not only accommodate people but provide } \\
\text { a variety of housing types and employment opportunities. There are people } \\
\text { that actually want single detached housing and do not want to live in } \\
\text { condominiums in urban cores. } \\
\text { Municipalities need to make sure they have enough designated land ready for } \\
\text { future employment opportunities and investment. This can be secured } \\
\text { through the PPS that allows municipalities to plan for strategic employment } \\
\text { opportunities past } 2041 \text {. } \\
\text { Importance of providing an array of housing types for the market by looking } \\
\text { at demand and not solely density. }\end{array}$ \\
\hline
\end{tabular}




\begin{tabular}{|c|c|}
\hline Development Industry & $\begin{array}{l}\text { - The GGH will be bringing in close to } 4 \text { million people in the next } 25 \text { years } \\
\text { and this will require municipalities to forecast and project for how and where } \\
\text { growth will be accommodated. } \\
\text { - Whitebelt land will need to be used to account for where most of the } \\
\text { necessary development will need to take place, including not just housing } \\
\text { but employment opportunities, infrastructure and future transit. } \\
\text { - Need greater housing types to be built especially on the urban fringe. }\end{array}$ \\
\hline Conservation & $\begin{array}{l}\text { - If the GGH is anticipating } 4 \text { million new residents by } 204,1 \text { then the lands } \\
\text { within the whitebelt are very important in order to accommodate the } \\
\text { projected growth. There should be no pressure to develop outside of the } \\
\text { whitebelt and into the Greenbelt. } \\
\text { - A land needs assessment is important to ensure that most of the future growth } \\
\text { for housing is centred within the built boundary or close to major transit } \\
\text { stations. } \\
\text { - The vision of smart growth policies should be applied. }\end{array}$ \\
\hline $\begin{array}{l}\text { Environmental } \\
\text { Organization }\end{array}$ & $\begin{array}{l}\text { - There is enough land to accommodate all projected population and } \\
\text { employment growth to the planning horizon of 2041, meaning that there } \\
\text { should be no need for municipalities to expand into the whitebelt. }\end{array}$ \\
\hline \multicolumn{2}{|c|}{ Topic Three: The Question of Land Supply } \\
\hline Academic/Research & $\begin{array}{l}\text { - These lands should be available for development if need be and not frozen, } \\
\text { like those within the Greenbelt. } \\
\text { - Whitebelt land should not only be held for urban expansion but should be } \\
\text { planned ahead. Servicing and infrastructure should be planned ahead of the } \\
\text { current } 2041 \text { horizon by municipalities, especially large projects including } \\
\text { highways, trunk sewers and corridors. }\end{array}$ \\
\hline Regional Planning & $\begin{array}{l}\text { - There is a need for modest settlement expansion to accommodate growth to } \\
\text { 2041. The majority of growth can be put into existing designated greenfield } \\
\text { areas (DGA). Even more intensification can be put into existing } \\
\text { communities and where it cannot be accommodated some settlement } \\
\text { expansion will be needed and appropriate. } \\
\text { The issue is not black and white, especially in the planning world. The issue } \\
\text { of the whitebelt and land supply is very much a regional and municipal level } \\
\text { issue that will be addressed differently by each municipality. Some } \\
\text { municipalities need to be able to look towards the whitebelt as a form of } \\
\text { investment into the area and as a way to provide opportunities for activity, } \\
\text { including transit possibilities that could have a huge impact on the } \\
\text { municipality. For other municipalities, the development of the whitebelt } \\
\text { might not be as significant. } \\
\text { Decisions surrounding the whitebelt are just as important for urban } \\
\text { communities as they are for rural communities, which is sometimes } \\
\text { forgotten when thinking about the whitebelt. }\end{array}$ \\
\hline
\end{tabular}




\begin{tabular}{|c|c|}
\hline Municipal Planning & $\begin{array}{l}\text { - For some municipalities the question of land supply is much more pressing } \\
\text { than in others. Some do not have the ability to continue growing outward and } \\
\text { therefore infill and intensification is their focus, while other municipalities } \\
\text { have the ability to accommodate greater urban fringe development and } \\
\text { potential low density housing. In some municipalities where the whitebelt } \\
\text { touches, intensification and high density built form is not necessarily } \\
\text { appropriate. }\end{array}$ \\
\hline Development Industry & $\begin{array}{l}\text { - There will be boundary expansions in the future but they will be quite small } \\
\text { in comparison to the } 2031 \text { target. Some municipalities might not even need } \\
\text { to expand if land has been used efficiently in order to accommodate targets. } \\
\text { - Importance of having serviced land ready for development when it is needed. } \\
\text { - Brought up the idea of "mini-whitebelts" around municipalities in the outer } \\
\text { ring municipalities that would benefit from having a buffer between their } \\
\text { boundaries and the Greenbelt. } \\
\text { Strategically having a buffer avoids the conversation about the Greenbelt for } \\
\text { several decades. Expansion of the Greenbelt into the whitebelt would be a } \\
\text { bad idea because it would put the Greenbelt into the cross fires of debate. }\end{array}$ \\
\hline Conservation & $\begin{array}{l}\text { - The whitebelt represents and encompasses a significant amount of lands that } \\
\text { are not homogenous and need to be treated in a manner that respects } \\
\text { environmental features. Necessary studies and reviews need to be completed } \\
\text { to ensure that development is appropriate. }\end{array}$ \\
\hline $\begin{array}{l}\text { Environmental } \\
\text { Organization }\end{array}$ & $\begin{array}{l}\text { - Contains important components of the regional agricultural and natural } \\
\text { heritage system that store vast quantities of carbon, help to reduce the risk } \\
\text { of flooding and provide valuable services which benefit all urban and rural } \\
\text { communities across the GTHA and GGH. } \\
\text { - Should be looking at the whitebelt land as a land supply to help enhance the } \\
\text { agricultural system in place already. This will have a large impact on food } \\
\text { security and access in the future. }\end{array}$ \\
\hline \multicolumn{2}{|c|}{ Topic Four: Environmental Significance and Potential Greenbelt Expansion } \\
\hline Academic/Research & - The Greenbelt should not be expanded into the current whitebelt lands. \\
\hline Regional Planning & $\begin{array}{l}\text { - Expansion of the Greenbelt should be rooted on a technical basis for a } \\
\text { specific purpose. It should not be arbitrary because it will have significant } \\
\text { impacts. Likewise, decisions around settlement expansion need to be } \\
\text { deliberate and should not just happen without objectives and complete } \\
\text { communities in mind. Expansions need to be on both sides and not just a } \\
\text { numbers exercise but should be focused. } \\
\text { - Need a deliberate rural planning framework that is much more inclusive in } \\
\text { order to ensure that farming can be sustained and profitable. Agricultural } \\
\text { lands won't thrive if just exclusive farmers and developers are holding land. }\end{array}$ \\
\hline
\end{tabular}




\begin{tabular}{|c|c|}
\hline Municipal Planning & $\begin{array}{l}\text { - It should be that there is a mixture of opinions from residents when it } \\
\text { comes to the development of whitebelt land and the Greenbelt } \\
\text { designation. } \\
\text { - Some land owners (particularly farmers) are unhappy because the } \\
\text { market prices of their farms are significantly less within the Greenbelt } \\
\text { than those that are within prime agricultural lands which developers are } \\
\text { investing in. }\end{array}$ \\
\hline Development Industry & $\begin{array}{l}\text { - Expanding the Greenbelt will actually weaken the purpose of it. The } \\
\text { whitebelt is the buffer between development and the Greenbelt. It is crucial } \\
\text { to make sure that there are policies in place to have room for some growth } \\
\text { without impacting the Greenbelt and the intent of it. } \\
\text { Expanding the Greenbelt into the whitebelt would ultimately begin to land } \\
\text { lock the existing urban area. This would be detrimental because growth is } \\
\text { still necessary (even in the long term). A balloon like effect would be created } \\
\text { and the existing urban area would begin to be squeezed and constrained by } \\
\text { the over regulation of surrounding rural lands. } \\
\text { - Politically and strategically having a buffer avoids the conversations about } \\
\text { the Greenbelt for future decades. } \\
\text { The importance of the whitebelt is therefore not just as a long-term urban } \\
\text { reserve but as a buffer or safety valve. } \\
\text { Will not be the 'wild west' of development since there are policies to ensure } \\
\text { that significant environmental features will be protected from development. }\end{array}$ \\
\hline Conservation & $\begin{array}{l}\text { - Any expansion should be based on good science and a methodology that } \\
\text { supports this. } \\
\text { - Need to make sure that growth is done in an environmentally appropriate } \\
\text { manner with overall goals to combat climate change and sprawl through } \\
\text { transit supportive means. There is no need to develop the whitebelt prior to } \\
2041 \text { so there should be little pressure to do so. }\end{array}$ \\
\hline $\begin{array}{l}\text { Environmental } \\
\text { Organization }\end{array}$ & $\begin{array}{l}\text { - Expanding the Greenbelt into the whitebelt will help build resiliency for } \\
\text { communities in the face of climate change and other uncertainties by } \\
\text { strengthening the ecological services and functions that agricultural lands, } \\
\text { water resources and natural areas provide. } \\
\text { Expanding the protections of the Greenbelt into whitebelt lands will support } \\
\text { and reinforce functionality of fragile systems in the Greenbelt, and in the } \\
\text { broader region. For example, many of the headwaters of the Humber and } \\
\text { Rouge rivers and Carruthers Creek are not protected by the Greenbelt and are } \\
\text { located in the northern parts of the whitebelt. Protecting vital and significant } \\
\text { resources should be at the forefront of the debate. }\end{array}$ \\
\hline \multicolumn{2}{|c|}{ Topic Five: Commentary on Updated Growth Plan Policies } \\
\hline Academic/Research & $\begin{array}{l}\text { - Lack of economic support and hard numbers in Provincial policies, which } \\
\text { leads to a disconnect between the polices presented and the market realty. } \\
\text { This is probably the biggest impact on housing prices and affordability in the } \\
\text { GTHA. }\end{array}$ \\
\hline
\end{tabular}




\begin{tabular}{|c|c|}
\hline Regional Planning & $\begin{array}{l}\text { Provincial land use policy framework and the key plans are overall very } \\
\text { consistent with the regional mandate. The strategic objectives of the region } \\
\text { strive to combat climate change and sprawl, while ensuring a high quality of } \\
\text { life for residents. It can be challenging at times to conform to though because } \\
\text { there are so many layers to work through but broadly speaking the policy } \\
\text { directions and targets of the Growth Plan are consistent in the region. } \\
\text { - Currently undertaking a Regional Official Plan review in order to conform } \\
\text { to the new and updated growth plan policies. }\end{array}$ \\
\hline Municipal Planning & $\begin{array}{l}\text { Provincial policies are sometimes constraining for a multitude of reasons } \\
\text { and there are a lot of layers to work through to ensure that municipalities are } \\
\text { conforming to Plans and policies within. }\end{array}$ \\
\hline Development Industry & $\begin{array}{l}\text { - It is builders that actually implement the Growth Plan and vision of it. } \\
\text { Builders provide the on the ground reality that turns policies into } \\
\text { communities, houses and jobs. Provincial policies are therefore a significant } \\
\text { aspect of the development industry and can critically impact development, } \\
\text { real estate and land supply. }\end{array}$ \\
\hline Conservation & $\begin{array}{l}\text { - The updated Growth Plan should be seen as successful for incorporating the } \\
\text { importance of sub-water sheds in the GGH into policy that municipalities } \\
\text { must look at. Any development of the whitebelt will need incorporate a } \\
\text { completed sub water shed study to prove that development will not disrupt } \\
\text { or have adverse effects on the environment. } \\
\text { The Province did a good job of setting the tone for how the whitebelt should } \\
\text { be defined and viewed for development through the requirement of a sub- } \\
\text { water shed study and storm water management plans. The use of low impact } \\
\text { development and green infrastructure is also an important component of } \\
\text { growth and development for the future. }\end{array}$ \\
\hline $\begin{array}{l}\text { Environmental } \\
\text { Organization }\end{array}$ & $\begin{array}{l}\text { - The amended Growth Plan incorporates policies that means the need for } \\
\text { municipalities to expand into the whitebelt is not necessary. New density } \\
\text { and intensification targets will allow municipalities to see more growth } \\
\text { within built-up boundaries and will provide an opportunity for communities } \\
\text { to prioritize protecting and enhancing the agricultural and natural heritage } \\
\text { systems in their respective geographies. } \\
\text { The importance of safeguarding these lands for agricultural and related uses } \\
\text { is necessary. }\end{array}$ \\
\hline
\end{tabular}

\subsection{Defining the Whitebelt}

A necessary starting point was to determine if there was common definition of the whitebelt among the participants. It was evident throughout the interview process that there was not a shared view of the whitebelt and that the interpretation of these lands seemed closely aligned with each participant's professional mandate. Each of the participants viewed the issue through a different 


\section{BEYOND THE BUILT BOUNDARY}

lens and perspective. The findings highlight that perhaps the most challenging aspect of the topic is that there is not a formal definition of the whitebelt and that the current policy framework at neither the Provincial nor municipal level make mention of the word explicitly. What is known is that the whitebelt encompasses lands that are within the Growth Plan (2017) and are designated as Prime Agricultural Areas and rural areas. Two of the participants felt that these designations have been designed, arguably intentionally, to be vague and therefore have become subject to great interpretation. It is this aspect of the Growth Plan and the policies for agricultural land not within the Greenbelt that have made these lands so contentious for growth and development. This was evident in each of the participant's responses. Only one participant argued that the whitebelt is clearly defined in the Growth Plan and contains primarily land designated Prime Agricultural Area.

Of the six participants, two felt strongly that the current policies provide a strict regulatory framework for how the lands should be interpreted. They pointed out that a significant majority of these lands are designated as Prime Agricultural Area, which mitigates development on these lands. When it comes to settlement boundary expansions Prime Agricultural Areas should be avoided with reasonable alternatives, and if these areas cannot be avoided by a municipality then lower priority agricultural lands should be used (Growth Plan for the Greater Golden Horseshoe, 2017). This is to say that there is already a level of protection on these lands through Provincial policy that offers some form of fortification against development in the short term. However, unlike Greenbelt lands long-term development may be permitted so long as the appropriate studies, analyses, assessments and reviews have been completed. One of the participants argued that the definition of the whitebelt, although not explicitly written in policy, is not up for interpretation because of the Prime Agricultural Area designation and therefore the policies of the designation 


\section{BEYOND THE BUILT BOUNDARY}

will dictate the future of the whitebelt lands. Another participant felt that the definition of the whitebelt was also very clear and argued that these lands should be looked at for future protection and not for growth.

Taking a different approach to the topic, one of the participants felt that the whitebelt and the development of it should be seen as municipally contextual and defined based on local need. Although this idea does not provide an over-arching definition, there is merit in talking about the whitebelt not as a single homogenous area. Whitebelt land in Vaughan will need to be addressed in a significantly different way than in Hamilton or Caledon, not only because of the size of whitebelt land in each of the municipalities, but in the way in which development will be focused. The participant argued that because many municipalities and urban areas are almost maximized in terms of built up areas there is a need to look beyond the built boundary. The purpose is to provide the market and residents with a variety of housing types and employment opportunities that in the future might not be able to be accommodated in much of the existing urban cores. The participant argued that in doing so it also allows municipalities to make growth a political priority and take control of planning in the area to allow for intentional and necessary growth over the longer term.

One of the participants stated that the core issue of the whitebelt is the simple fact that there is not a singular definition for it. This is highly problematic and highlights why this issue has become so contentious. The participant pointed out that there is currently no definition plainly set out by the province and has created an environment of developer speculation, high land prices and inconsistencies. The argument was that the province, by not recognizing the whitebelt as a designated area like the Greenbelt in the updated Growth Plan (2017), is tip-toeing around the issue of defining and handling how these lands should be seen. The participant argued that since the whitebelt encompasses land that is intended as a long term urban reserve, then the province 


\section{BEYOND THE BUILT BOUNDARY}

should provide clearer policies surrounding how these lands should be viewed in the long term. In the absence of formally recognizing the whitebelt as a designation, like the Greenbelt, it has created a highly speculative real estate market for lands viewed as long term driven mainly by the development industry. Half of the participants made mention of the fact that a large percentage of whitebelt land is currently held by developers. Many of these transactions have been quite profitable for the land owners that sold their land, especially for those whose properties are located just along the urban fringe beside the built boundaries. This speculative environment has made agricultural land highly desirable for developers to hold with the hopes that the land will be brought into the boundary. Until then the land remains for strictly agricultural purposes as whitebelt land.

\subsection{Impacts on Housing and Employment Demand}

Throughout all interviews the impact of housing affordability and supply became central to the topic of the whitebelt and provincial planning debate. Of the six participants over half felt strongly that future housing demands will greatly shape how development will occur within the GTHA, especially with regards to the types of housing being built. As argued in the report by Given et al., (2017) "the provision of sufficient housing to match population growth is in crisis, particularly with regard to single and semi-detached forms of housing which continue to be the preferred choice for housing families" (5). Amborski and Clayton (2017) argue that the expansion of serviced land supply for ground related housing will need to happen sooner rather than later and will take place largely in the 905 where this type of housing can be accommodated on current and future vacant lands (1). Two of the participants made the point that having either existing or planned servicing is crucial for both market demands and investment for future housing. Having infrastructure in place to ensure growth can be accommodated in a timely manner is highly significant. 


\section{BEYOND THE BUILT BOUNDARY}

Half of the participants shared the same sentiment that ultimately not everyone wants to live in a condominium or apartment, and because of this the market will demand more low density, single family housing to be built. This view seems to run counter to the goals of both Growth Plan versions which were created to ensure that the way municipalities grew in the GGH would limit sprawl and greenfield development in favour of greater infill development and intensification. The push for greater intensification has been one of the key pieces of Provincial policy directing growth. Arguably because of this it can be seen that "two out of three new homes built today are multi-family, up from less than half in the mid-2000s" ("Emerging Trends in Real Estate 2018"). One participant remarked that because of these housing demands the intensification piece of this debate is therefore going to get increasingly complex. Four of the participants felt as though the demand for single family homes is still strong and despite Provincial policies there is a need to recognize market demands. As a result, there will need to be more greenfield development over the next few decades. One of the participants made explicit that they felt that planners are more concerned with meeting policy than looking into the reality of the numbers. They argued that currently there are no incentives for planners to be concerned with the economy and housing demand. The planning system is arguably one of the leading factors in why housing prices have gone up and has impacted the delivery of serviced land in a timely manner for regional and municipal growth.

One of the participants pointed to the significance of municipalities to plan for future employment uses beyond the scope of the 2041 Provincial policy targets. Municipalities must ensure that there is enough land supply to not only meet the needs of housing, but to ensure that there is suitable land for designated employment areas in order to attract future investment and secure new employment opportunities. This argument highlights a key point about the need for urban land reserves in order for regions to not only grow but attract residents and jobs alike. To be 


\section{BEYOND THE BUILT BOUNDARY}

able to accommodate employment opportunities is imperative and will greatly contribute to a strong market. As the participant argued investment through jobs and employment should also be taken into consideration when looking at demand and not just housing. Future development of parts of the whitebelt is therefore a vital component of how and where GTHA will not only grow but provide residents with a place to live and work.

\subsection{How Lands Should Be Addressed}

One of the questions specifically asked participants in your professional opinion how should the province and municipalities address lands within the whitebelt. Of the six, four participants felt strongly that these lands should be held for urban expansion and viewed as a reserve that should not be 'frozen'; however, the extent to which the whitebelt was seen as a place for modest expansion was not a shared sentiment. Differing professional backgrounds and opinions were perhaps most evident with the responses to this question. It highlighted the intrinsic complexities and challenges that comes from the discussion of land supply. Some view them as "raw" and developable, while others argue for their protection due to their environmental and agricultural significance.

Two participants felt that proper consideration was not being given to the actual numbers and questioned where and how population projections were being calculated. It was made evident that they felt that the importance of having concrete and reliable projections was a necessity for density targets, demand and future growth, especially when considering immigration. At least four of the six participants argued that because of the economics behind population growth, some modest expansion in the whitebelt would be necessary in the near future. Certainly some municipalities will require greater boundary expansions over others that will not need to open up 


\section{BEYOND THE BUILT BOUNDARY}

more land to development. In order to determine this, municipalities will, as aforementioned earlier in the paper, need to conduct an MCR and provide a land needs assessment in order to expand the boundary. As one participant outlined, municipalities need to be able to show that even after taking into consideration vacant and greenfield lands, the need for greater yet reasonable expansion is still necessary.

Throughout one of the interviews a different discussion around the whitebelt came up that asked the question whether the concept of a whitebelt should actually increase to encompass other significant areas of the land outside of the inner ring. The participant posed the question of whether the creation of "mini-whitebelts" could help to ensure that other municipalities, especially in the outer ring, would have the ability to designate purposeful urban reserves. In this context the intent of the whitebelt would be an actual designation that would be used by the province to provide an intentional buffer for some municipalities facing development pressures and Greenbelt expansions. This could be used in the City of Barrie for example. Barrie is at risk of being potentially impacted by the Greenbelt expansion, however, the town is also experiencing a high level of development activity and is undergoing expansion through the creation of Secondary Plans. The participant argued that for some the fear of a Greenbelt expansion into municipalities that are already developing could be very constraining on the market. The idea of the "miniwhitebelts" along municipalities urban fringes provides an interesting layer to the argument that the lands in the whitebelt have been maintained as an urban reserve and have an important role in safeguarding for growth in the future. 


\subsection{Environmental Significance and Potential Greenbelt Expansion}

In December 2017 the province of Ontario proposed the expansion of the Greenbelt into areas of the outer ring of the GGH in a bid to protect clean water sources from urbanization, development and climate change (Kalinowski, 2017). The province is currently studying seven areas that total about 345,000 hectares from Simcoe County to Niagara Region, to assess whether or not the expansion of the Greenbelt over parts of these areas would help to mitigate development in environmentally sensitive areas (Kalinowski, 2017). A coalition of environmentalists and conservationists want the province to expand the study area and create a "bluebelt that would include key watersheds and vulnerable areas in Wellington County and the south shore of Lake Ontario" (Kalinowski, 2017). This recent initiative and consultation process by the province, although focused in the outer ring, brings to question the possibility of potential expansion of the Greenbelt south into the inner ring.

When it came to the question around the Greenbelt and if expansion into parts of the whitebelt should be taken into consideration, there was a sharp divide amongst participants and their responses. Two of the six believed that re-designating parts of the whitebelt to be within the Greenbelt would be beneficial to help conserve the natural resources within the lands. It was also argued that it could help to mitigate climate change effects and contribute to building more resilient communities. The concern was that if the whitebelt lands are not safeguarded against development, then the loss of the environmentally rich and significant land would far outweigh the benefit of development and undermine the original intent of Provincial policies that focus on creating and maintaining healthy, safe and complete communities. One of the participants pointed out that municipalities should be encouraging compatible uses and avoid making irreversible land use decisions that undermine agricultural operations and environmental resources and functions. This 


\section{BEYOND THE BUILT BOUNDARY}

includes the vast sub water sheds that are situated all throughout the GGH and the entire province. These water sheds make up a significant network of environmental features containing vital water resources. The Province in the updated Growth Plan recognized the need for protection and made sub water sheds and their studies a large component of planning for the future.

There is a necessity when thinking about the whitebelt and the land within as a reserve system, that the intent of the Greenbelt be assessed in conjunction with. Similar to the Wilson (2013) article, there have been a number of articles that have called for not only the protection of the current Greenbelt boundaries but an expansion into areas that are not currently within the Greenbelt, yet contain significant environmental features. One of the interviewees pointed to the need for Greenbelt expansion as a necessity to protect the lands within the whitebelt from future development because it not only contains key agricultural and environmental features, including habitats and ecosystems that are essential to the future of the entire GGH, but also allow farmers to flourish.

Yet, the Greenbelt has also inherently created much of the problems that are currently being faced with regards to land use planning. One participant went so far as to say that from a societal point of view there is enough "green" in the GTHA. Of those interviewed, two out of the six recognized this and suggested that the Greenbelt is a hardline designation that has created a scenario where the GTHA is like a growing balloon slowly being squeezed. One of the participants made a point that when you have frozen land, as is the case of the Greenbelt, you create dichotomygrowing and constricting all at once. The question is therefore when and what will happen when it pops. Two participants felt strongly that the culprit of all this is the overly regulated policies of the Greenbelt Plan and the Growth Plan. When put together, they create a housing market that is slowly being squeezed and constrained by access to developable land. By cutting off the supply of 


\section{BEYOND THE BUILT BOUNDARY}

land for new houses, especially detached or semi-detached, it is hard not to argue that these pieces of legislation have played a major role in driving up the prices across of the GTHA (Gray, 2016).

One of the participants made the argument that the whitebelt is a necessary safety valve, for not only long term need, but as a separation between the built boundaries and protected Greenbelt land. The whitebelt therefore needs to be seen as a buffer for the Greenbelt that was established to not only protect the productive lands, but to ensure the health and vibrancy of the cities within the entire GGH. The participant responded that although these lands are to be a functional buffer containing productive farmland, the question of future development should not be taken off the table. Municipalities will need to grow and when they do, the whitebelt lands that are currently on the urban fringe will be where development will need to be directed.

\subsection{Commentary on Updated Growth Plan Policies}

The findings from five of the interviews prove that the primary challenge impacting the whitebelt is Provincial land use policies and the way in which the planning process works at both a Provincial and municipal level. This may not seem like a new revelation and should be fairly evident but there is still to some degree a disconnect between the policies of the Growth Plan and market realities. One of the participants pointed to the complexity of Provincial policies and the challenges of ensuring conformity when there are so many layers to work through. From a municipal planning point of view to provide not only new housing and employment opportunities but the protection of farmland and existing livelihoods can be challenging. Different scenarios can begin to play out when trying to conform to policies that require different targets, densities, and affordability in relation to current land supply. The participant made clear that although working through all layers of policy can be difficult, ultimately both versions of the Growth Plan have been 
successful in creating a clear vision for how the GTHA and GGH should continue to grow. They argued that thankfully the 2006 policies were able to begin to combat sprawl through greater intensification and infill within exiting areas. Due to these policies the necessity of developing whitebelt land and rural lands on the urban fringe has declined.

On the contrary, these targets were also scrutinized by two of the participants in wake of the updated policies around greenfield development and density. One of the participants disputed that the new greenfield density target, which is now $80 \%$ people and jobs per hectare, promotes inappropriate forms of growth on the urban fringe where this type of intensification is not supported (Growth Plan for the Greater Golden Horseshoe, 2017). Arguably few of these fringe locations are close to existing or even planned transit hubs. This makes directing higher densities to these areas a potential recipe for greater traffic congestion and other adverse planning effects (Given et al., 2017,9). Given et al., (2017) argues that these updates represent "a perverse planning approach that would direct some of the highest densities in the GTHA to the fringe of urban development, directing density away from intensification" (9). Figure 4 provides an illustration of the built form around the higher density targets located in greenfields and expansion areas which would include whitebelt lands.

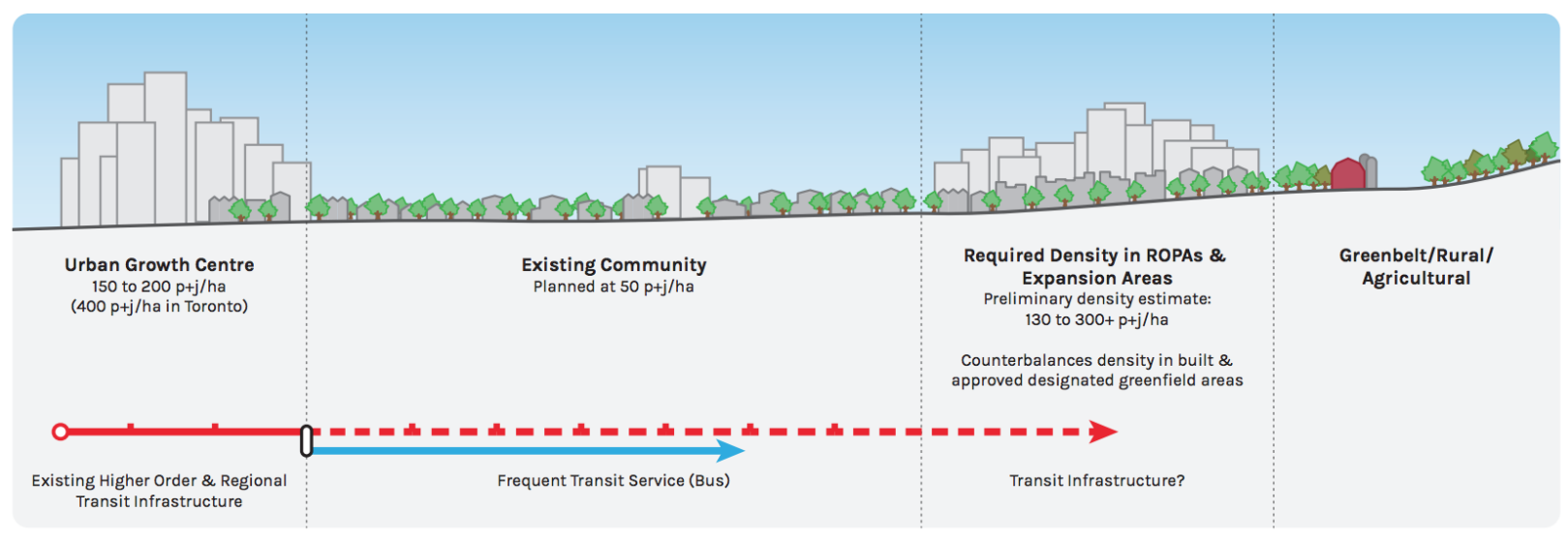

Figure 5 Illustration of Urban Nodal Densities to the Periphery (source: Given et al., 2017, p. 9) 


\section{BEYOND THE BUILT BOUNDARY}

The argument is that the province in its calculation for the updated target was relying on a flawed understanding of development land. In the analysis, the Province "only considered what was actually built and did not consider lands at a stage of approval that cannot be reversed, otherwise referred to as committed" (Given et al., 2017 8). This is a very important aspect of the argument that comes back to the very question of what the whitebelt is- how are land inventories calculated in the face of designated, planned and approved sites, and what is the true land supply?

One of the participants jokingly argued that, despite what many fear, the whitebelt is not going to be the wild west of development. Any sort of growth in this area will need to be dictated through studies, analysis and reviews. This will ensure that it is done in such a way that meets the targets and vision of the Growth Plan. There are a lot of tests already built into the planning process which will help to ensure that whitebelt lands will not be 'eaten up' quickly because ultimately these lands are not homogenous. The whitebelt encompasses environmentally sensitive areas and urban river valley systems that will require take outs to be done and a comprehensive master servicing plan to be undertaken by regions.

Five of the six participants ultimately argued that the importance of municipalities planning beyond 2041 is crucial to the debate around the whitebelt and is perhaps a good reason for formalizing the whitebelt in policy. One participant argued that policy allows municipalities to better plan for servicing and important large scale infrastructure projects that will help to make parts of the GTHA better equipped for future growth and investment. Planning for long term servicing is also a vital component of ensuring sufficient housing supply in the long term. Ultimately, any sort of development in the whitebelt will need to be done through a municipal expansion that is already strictly laid out in policy. 


\section{Discussion and Recommendation}

Referring to the future of development within the whitebelt, Economist Brad Graham was quoted saying that "it shouldn't be a no, never it should be yes, but...", expressing that "we're sending a gentle reminder to the province that this land was set aside purposefully... as a future buffer" (Daniel, 2015). Although simplistic, the notion of "yes, but..." being the key to understanding the development of whitebelt lands is fairly accurate and provides a context for providing recommendations to better inform policy and how the future of whitebelt lands should be addressed. The conversation around the whitebelt can more often than not over simplify the topic and come across as though the lands within are in some way the same. The unique landscape that it encompasses will require a variety of layers to work through when developing these lands in the long term. Decisions will not be made hastily because there are currently strict policies in place when it comes to urban boundary expansions. What follows are three recommendations that have been built off of the research conducted and the responses from the participants. These recommendations should be seen as a starting point for a greater conversation around the whitebelt in both literature and planning documentation.

\section{Recommendation 1: Formal recognition in Provincial policy}

Inconsistencies in defining the whitebelt have created a divide in opinion between how these lands should be regulated in current and future Provincial policies. One of the key recommendations is the need for the province to formally recognize and define the lands within planning policy as a long term urban reserve. While the term whitebelt is known within the planning practitioners and the development industry, it remains an informal definition. This has created a disconnect between understanding what these lands are currently regulated as, and how 


\section{BEYOND THE BUILT BOUNDARY}

they will be designated in the future. Without a concrete definition various interpretations have made these lands contentious with the fear of either being developed or alternatively not. If there was formal recognition that whitebelt lands were urban reserve areas intended for long term growth, there could be a level of reinforcement as to how these lands will be retained for the future. Although the Province already provides a comprehensive and reasonable designation for Prime Agricultural Areas, there is an opportunity for the province to provide a long term policy framework to limit speculation and loose interpretation.

Arguably the lack of recognition is a political maneuver to strategically not enter into the debate on either side, a point put forth by one of the participants. This can be interpreted as a political move to purposefully not designate these lands, thereby removing the province from controversial decision making. Push back by industry professionals against the Greenbelt has created a contentious planning environment around designations and the overregulation of land. The Prime Agricultural Areas designation can therefore be seen as a placeholder for the short term protection of these lands and future growth, without overly restrictive policies in either direction. Despite this, there is a strong case to be made to have the whitebelt be formally recognized in Provincial policies, to ensure the proper protection of these lands in both the short and long term.

A distinguishing feature of the Ontario's current planning policy framework is the importance of the Greenbelt for the future health and vibrancy of the GGH. These lands contain highly significant agricultural areas that comprise vital farmland that not only feed cities but are representative of thousands of farmers and livelihoods (Wilson, 2013). The issue of food security provides a compelling argument alone to sustain the Greenbelt in its intent as a Provincially recognized and protected part of the GGH. The policies put forth in the Greenbelt Plan contribute to the safety of these lands from development pressures in order to protect significant 


\section{BEYOND THE BUILT BOUNDARY}

environmental lands from being redeveloped or adversely affected. These areas not only contribute to food security and production, but to air quality, significant watersheds, streams and riverbeds, and can help to mitigate the impacts of climate change that is very much evident and ongoing (Greenbelt, 2006/2017). Yet, how heavily should the lands be regulated? The Greenbelt is successful in protecting the land that it designates. However, as a policy that contributes and works in conjunction with several other layers of policies, at both provincial and municipal levels, the Greenbelt has also regulated and contributed to a speculative real estate market, high land prices and leap-frogging. This brings to question the validity of recommending the Province formally recognize the whitebelt, if the Greenbelt is already a very contentious debate in the provincial planning realm. The point to be made is on the benefit of province at least addressing and defining the whitebelt to ensure that it remains as a buffer zone to benefit municipalities and local economy.

In the Advisory Panel Report led by David Crombie (2015) the report provided a comprehensive review of Provincial policies including the Growth Plan and the Greenbelt Plan. The recommendation from this report takes a protectionist stance towards whitebelt lands in favour of protecting agricultural uses. Yet, the recommendations from this report left a significant policy gap by failing to recognize alternative market forces that will impact the GTHA. This report provides an example of how the province has continued to delay the formal recognition of whitebelt lands and can be seen as a major shortcoming to the latest Growth Plan updates. The necessity of the province addressing and defining the whitebelt is fundamental to ensure that it remains as a buffer zone for future growth and development. Providing a definition would ensure a form of stability over these lands from high speculation that may impact the market, on either side of the pro-development or pro-environment debate. 


\section{Recommendation 2: Increase Role for Municipal Decision Making}

A further complication to defining whitebelt lands lies in the regional variations between municipal land needs and boundary expansion. From this it is recommended that local municipal involvement be imperative to implementing future policy direction for whitebelt lands. Based on the responses and opinions reveled by the participants in the interviews, the notion of creating "mini-whitebelts" would allow municipalities to have a buffer zone for future urban expansion. This would increase the role of municipal decision making for housing and employment opportunities based on a MCR and a comprehensive land needs assessment.

The argument is that planning policies need to recognize that municipalities will grow beyond 2041. In outer ring areas, some municipalities are in the predicament of having the Greenbelt pushed too closely to the urban boundary. The City of Barrie, for instance, has seen a lot of growth in the pipeline that could benefit from having a designated buffer. There is an opportunity for the Province to recognize this and designate and define the term whitebelt to be a long term reserve of greenfield land that acts as a buffer. This would allow municipalities the ability to look strategically at their own land supply and inventory for potential urban expansion while also providing a level of protection from being designated and restricted from development. Ultimately, the goal is to create complete communities. A large aspect of this is to have communities that are thriving and income generating places where people want to live and work. As one of the participants said 'not everything in the planning world is black and white' and requires a level of municipal and regional interpretation in order to better plan for communities at a local scale. 


\section{Recommendation 3: Need for Further Research}

The small sample size used in the interview process was a pre-test to better understand the need for a future study using a larger scope of stakeholders. The summary of the findings presents a small range of opinions and insightful results which can add to the existing literature on the topic; however, the need for greater inquiry is still necessary in order to fully grasp the complexities of the issue and to provide a more comprehensive response for policy interventions. Future research must incorporate a larger sample size of stakeholders and consider the diverse geographic range that the whitebelt encompasses. This may include a range of opinion based on regional interests, current housing and employment characteristics and future planning needs. It is anticipated that based on differing regional geographies, this may render different results in stakeholder opinion. As documented in the report's findings, the conflicting responses by the six participants demonstrates the complexities of understanding a topic that is rooted in a small depth of literature. Interpretation of the interviewees responses showed that there was little consensus overall because of the different meanings each participant had and the lens that was used to inform their opinions.

As a topic that has had little written on it there is also a need for further study to better capture the current status and supply of whitebelt land. Although there are few studies that provide an inventory of land there is a need for current information on the whitebelt especially following the updated Provincial policies. Maps of whitebelt land would be helpful at a regional scale to better understand what significant environmental features are encompassed within and their

proximity to existing settlement areas. There is also a strong need to perform interviews with a larger variety of stakeholders to try and more accurately capture opinions on the subject of the whitebelt. 


\section{BEYOND THE BUILT BOUNDARY}

Overall, the six interviews were intended to be a pre-test to better understand whether or not future research would be necessary on the topic. Having six participants guide the research was necessary to refine the interview methodology and line of inquiry in support of a broader future study with a greater variety of stakeholders. 


\section{BEYOND THE BUILT BOUNDARY}

\section{Conclusion}

There is a point to be made about the current state of politics in Ontario since the Provincial planning process is top down and heavily political. A Provincial election is set for June 2018 and depending on the outcome it could have an impact on the current policies. The Growth Plan was put forth and carried out under an entirely Liberal government and the vision and policies within are the products of this party. It is hard to speculate what other governments may do in power but planning is a very top down approach in Ontario and much of the authority comes from the province. Should the system be changed it can be expected that there would be significant impacts on the planning process. However, if the current Liberal government is re-elected there is a strong case to be made that perhaps the same issues associated with the housing affordability crisis and over regulation of land would be maintained, if not exacerbated. Nonetheless, it should be seen that whitebelt land will remain a highly topical issue in Ontario and how the future of these lands will continue to be addressed by the province over the coming years and decades.

Through a comprehensive literature review, case study and semi-structured interviews with six stakeholders, this paper has sought to answer the question: What is the current state of professional opinion related to the future development of whitebelt land in the Greater Toronto and Hamilton Area (GTHA) that can better inform policy and how the future of whitebelt lands should be addressed? The interview findings revealed the lack of formal definition attributed to the whitebelt. Even though each participant provided meaningful and insightful contributions to the issue and helped to better understand the topic, all six participants approached the notion of the whitebelt from a variety of perspectives and a different definition. It was these findings that provided the basis for a recommendation to call upon the province to provide a definition and formal recognition of the whitebelt in policy to limit interpretations and speculation. In order to 


\section{BEYOND THE BUILT BOUNDARY}

provide a context for the whitebelt on a local scale, the need for municipal decision making is significant.

The stakeholder interviews established that further research is essential. They identified the need to refine the survey questions asked to "drill down" to better articulate the basis of the differences of opinion that were presented. They also identified that other potential stakeholders should be considered in future research. From the analysis presented in this paper, there is a hope for greater study as to how best approach the topic of the whitebelt in the long term. As a safety valve for both the health and longevity of the GTHA the whitebelt is significant for future growth and should no longer be a grey area in planning policy. 


\section{References}

Allen, Rian and Philippa Campsie (2013). Implementing the Growth Plan for the Greater Golden Horseshoe: Has the strategic regional vision been compromised? Toronto: The Neptis Foundation. Retrieved from, http://www.neptis.org/sites/default/files/growth_plan_2013/theneptisgrowthplanreport_final.pdf

"An update on the total land supply: Even more land available for homes and jobs in the Greater Golden Horseshoe" (March 9, 2017). Toronto: The Neptis Foundation. Retrieved from, http://www.neptis.org/sites/default/files/land_supply_briefs_2016/an_update_on_the_total_land supply_even_more_land_available_for_homes_and_jobs_in_the_ggh.pdf

Clayton, Dr. Frank and David Amborski (2017) "Countering Myths about Rising Ground-Related Housing Prices in the GTA: New Supply Really Matters". Centre for Urban Research \& Land Development.

Crombie, David et al., (December 2015) Planning for Health, Prosperity and Growth in the Greater Golden Horseshoe: 2015-2041. Ministry of Municipal Affairs. Pg. 1-175.

Daniel, Diane (September 24, 2014) "What to do with the 'whitebelt' lands?" Toronto Sun. Retrieved from, http://torontosun.com/2015/09/24/what-to-do-with-the-whitebelt-lands/wcm/4be17a8d 2fa9-47fd-8ea2-10a3c321e850

"Discussion Paper: Proposed Methodology for Land Needs Assessment for the Greater Golden Horseshoe" (December 2017). Ontario.ca/placestogrow. Retrieved from, http://www.placestogrow.ca/images/pdfs/LNA/en/proposed_methodology_EN.pdf

Downs, Anthony (2005) "Smart Growth: Why We Discuss It More than We Do It" Journal of American Planning Association 71(4): 367-78. Retrieved from, https://www.tandfonline.com/doi/abs/10.1080/01944360508976707

Doyle, Victor (May 7, 2017) "The Growth Plan and the Greenbelt Plan: Setting the Record Straight”. StormCoalition.com. Retrieved from, http://www.stormcoalition.org/headline/Setting_the_Record_Straight.pdf

"Emerging Trends in Real Estate 2018". PwC.com. Retrieved from, https://www.pwc.com/ca/en/industries/real-estate/emerging-trends-in-real-estate-2018.html

Given, Donald, et al., (March 2017) "Getting the Growth Plan Right”. Malone Given Parsons Ltd. Retrieved from, http://www.mgp.ca/wp-content/uploads/2017/04/Getting-the-Growth-Plan-Right March-2017.pdf

Gray, Jeff. (October 14, 2016) "Is the greenbelt squeezing Toronto's housing market" The Globe and Mail. Retrieved from, https://www.theglobeandmail.com/news/toronto/is-the-greenbelt squeezing-torontos-housingmarket/article32369107/

"GTA West: Transportation Corridor Route Planning and Environmental Assessment Study, Stage 2". Gta-west.com. Retrieved from, http://www.gta-west.com/ 


\section{BEYOND THE BUILT BOUNDARY}

Kalinowski, Tess (December 8, 2017) "Ontario may expand Greenbelt to protect water supply" thestar.com. Retrieved from, https://www.thestar.com/business/2017/12/08/ontario-may-expand greenbelt-to-protect-water-supply.html

Ontario Ministry of Municipal Affairs (2017). Greenbelt Plan. Toronto: Queen's Printer for Ontario.

Ontario Ministry of Municipal Affairs. (2006). Growth Plan for the Greater Golden Horseshoe. Toronto: Queen's Printer for Ontario.

Ontario Ministry of Municipal Affairs (2017). Growth Plan for the Greater Golden Horseshoe. Toronto: Queen's Printer for Ontario.

McGrath, John Michael (February 6, 2015). "Developers and environmentalists respond to charges that the Greenbelt is driving up house prices", TVO. Retrieved on January 27, 2018 from, https://tvo.org/article/current-affairs/the-next-ontario/developers-and-environmentalists-respond to-charges-that-the-greenbelt-is-driving-up-house-prices

McGrath, John Michael (April 13 2017) "It Appears the GTHA is running out of land for new homes after all". TVO. Retrieved from, https://tvo.org/article/current-affairs/the-next-ontario/it-appears the-gtha-is-running-out-of-land-for-new-homes-after-all

Ministry of Transportation (February 9, 2018). "News Release: Ontario Not Moving Forward with Highway for GTA West Corridor". Retrieved from, https://news.ontario.ca/mto/en/2018/02/ontario-not-moving-forward-with-highway-for-gta-west corridor.html

Ministry of Housing and Affairs (n.d.) Performance Indicators For the Growth Plan for the Greater Golden Horseshoe, 2006. Retrieved from, http://www.mah.gov.on.ca/AssetFactory.aspx?did=10849

Ministry of Municipal Affairs and Housing (2014) Provincial Policy Statement. Planning Act.

Ministry of Municipal Affairs and Housing (n.d.) Protecting Water for Future Generations: Growing the Greenbelt in the Outer Ring. Retrieved from, http://www.mah.gov.on.ca/page17641.aspx\#executive_summary

Saminather, Nichola and Matt Scuffman (February 28, 2018) “Toronto's Housing Supply Challenge and the Growth Plan Paradox" Financial Post. Retrieved from, http://business.financialpost.com/real-estate/mortgages/rpt-insight-torontos-housing-supply challenge-and-the-growth-plan-paradox

Tomalty, Ray and Bartek Komorowski (June 2011). "Inside and Out: Sustaining Ontario's Greenbelt". Smart Cities Research Services. Friends of the Greenbelt. Retrieved from, http://d3n8a8pro7vhmx.cloudfront.net/greenbelt/pages/879/attachments/original/1383749838/in de_and_out_sustaining_ontario039s_greenbelt_.pdf?1383749838

"Understanding the Fundamentals of the Growth Plan" (March 20, 2015). Toronto: The Neptis Foundation.Retrieved from, http://www.neptis.org/sites/default/files/gp_primer/understanding_the_fundamentals_of_the_gr wth_plan_march20_0.pdf 


\section{BEYOND THE BUILT BOUNDARY}

"Vaughan white belt plan in works" Newmarket Era. September 10, 2010. Retrieved from, https://www.yorkregion.com/news-story/1464830-vaughan-white-belt-plan-in-works/

White, Richard (December 2007) "The Growth Plan for the Greater Golden Horseshoe: In the Historical Perspective" Paper 4: Neptis Papers on Growth in the Toronto Metropolitan Region. Retrieved from, http://www.neptis.org/sites/default/files/historical_commentary/historicalcomm_web_20071129 .pdf

"Whitebelt Visioning Exercise" (n.d.) Town of Caledon. Retrieved from, https://www.caledon.ca/en/townhall/Whitebelt.asp

Wilson, Sara (2013) "Nature on the Edge: Natural Capital and Ontario's Growing Golden Horseshoe". David Suzuki Foundation: Vancouver. 


\section{Appendices}

\section{Appendix A: Inventory of Whitebelt Land, By Municipality}

The calculations and table are provided by the Neptis Foundation in the article Implementing the Growth Plan for the Greater Golden Horseshoe (2013). The findings present an interesting look at the amount of whitebelt land that each municipality contained during the time of the study. These figures still provide relevant insight into the topic.

TABLE 3.13: INVENTORY OF WHITEBELT LANDS, BY MUNICIPALITY

\begin{tabular}{|c|c|c|c|}
\hline Upper- or Single-tier Municipality & Area & Lower-tier Municipality & Area \\
\hline \multirow{4}{*}{ Region of Durham } & \multirow{4}{*}{11,500 ha } & Municipality of Clarington & $4,600 \mathrm{ha}$ \\
\hline & & City of Oshawa & $1,100 \mathrm{ha}$ \\
\hline & & City of Pickering & $4,700 \mathrm{ha}$ \\
\hline & & Town of Whitby & $1,000 \mathrm{ha}$ \\
\hline \multirow{4}{*}{ Region of Halton } & \multirow{4}{*}{$11,700 \mathrm{ha}$} & City of Burlington & 500 ha \\
\hline & & Town of Halton Hills & $6,800 \mathrm{ha}$ \\
\hline & & Town of Milton & 4,300 ha \\
\hline & & Town of Oakville & $100 \mathrm{ha}$ \\
\hline Region of Peel & $11,300 \mathrm{ha}$ & Town of Caledon & $11,300 \mathrm{ha}$ \\
\hline \multirow{7}{*}{ Region of York } & \multirow{7}{*}{$6,200 \mathrm{ha}$} & Town of Aurora & $100 \mathrm{ha}$ \\
\hline & & Town of East Gwillimbury & $1,700 \mathrm{ha}$ \\
\hline & & Township of King & $100 \mathrm{ha}$ \\
\hline & & Town of Markham & 2,000 ha \\
\hline & & Town of Newmarket & $100 \mathrm{ha}$ \\
\hline & & City of Voughan & 1,800 ha \\
\hline & & Town of Whitchurch-Stouffville & $400 \mathrm{ha}$ \\
\hline City of Hamilton & $5,200 \mathrm{ha}$ & - & 5,200 ha \\
\hline Total & 46,000 ha & - & $46,000 \mathrm{ha}$ \\
\hline
\end{tabular}

${ }^{1}$ Calculated by the Neptis Foundation as determined through the review of municipal official plans, official plan amendments, and other planning documents; see Appendix A for methodology, Appendix B for sources, and Appendix C for the land area inventory by municipality, and the Greenbelt Plan Area defined though Ontario Regulation 59/05 by the Ontario Ministry of Municipal Affairs and Housing. 36 hectares in Niagara Region (Town of Grimsby) were not included in the total.

*Numbers may not sum to total due to rounding. 


\section{Appendix B: Total Designated Greenfield Area}

This chart was created by Malone Given Parsons in their report Getting the Growth Plan Right (2017) to show that the total hectares of designated greenfield areas is in reality committed and not vacant for development. It was argued that the Province was using a flawed system to show the total amount of greenfield land and has contributed to an updated density target that is much too high.

Figure 5 - MGP's Detailed Analysis Shows that 57\% of DGA Lands are Committed vs. the Province's Estimated 4.7\%

\begin{tabular}{|c|c|c|c|c|c|}
\hline \multirow[b]{2}{*}{ GTHA REGION } & \multirow[b]{2}{*}{$\begin{array}{c}\text { Total Designated } \\
\text { Greenfield Area } \\
\text { (ha) }\end{array}$} & \multicolumn{2}{|c|}{ MGP ANALYSIS ${ }^{1}$} & \multicolumn{2}{|c|}{ PROVINCIAL REPORTING ${ }^{2}$} \\
\hline & & $\begin{array}{l}\text { "Committed" } \\
\text { Designated } \\
\text { Greenfield Area } \\
\text { (ha) }{ }^{3}\end{array}$ & $\begin{array}{c}\text { \% of Total } \\
\text { Designated } \\
\text { Greenfield Area }\end{array}$ & $\begin{array}{l}\text { "Developing" } \\
\text { Designated } \\
\text { Greenfield Area } \\
\text { (ha) }\end{array}$ & $\begin{array}{c}\% \text { of Total } \\
\text { Designated } \\
\text { Greenfield Area }\end{array}$ \\
\hline City of Hamilton & 2,200 & 1,300 & $58.0 \%$ & 219 & $4.8 \%$ \\
\hline Region of Durham & 4,700 & 2,800 & $56.6 \%$ & 409 & $3.1 \%$ \\
\hline Region of Halton & 4,000 & 2,000 & $51.1 \%$ & 310 & $2.6 \%$ \\
\hline Region of Peel & 6,400 & 3,700 & $57.2 \%$ & 671 & $6.7 \%$ \\
\hline Region of York & 7,600 & 4,800 & $62.8 \%$ & 1,073 & $5.6 \%$ \\
\hline GTHA TOTAL & 24,900 & 14,400 & $57.9 \%$ & 2,682 & $4.7 \%$ \\
\hline
\end{tabular}

(1) Source: Malone Given Parsons Ltd., 2016

(2) Source: "Places to Grow Performance Indicators", 2015, Page 14

(3) Preliminary rounded estimates of Designated Greenfield Area as of 2006 and excludes Expansion Areas -Community Area (6,700 ha) and Employment Area (3,200 ha) 


\section{Appendix C: Core Interview Questions}

The following are the six core questions that each participant was asked during interviews. It is important to note that the questions were intended to be used as a starting point for conversation.

1. How does Provincial land use policy impact on your (firm's/organizations) mandate?

2. Does the potential development of "whitebelt lands impact your organization? If so, how?

3. In your professional opinion are the lands within the "whitebelt" important to the future of the GTHA (Greater Toronto and Hamilton Area)?

4. In your professional opinion how should the province and municipalities address lands within the "whitebelt"?

5. What is your opinion on potentially expanding the greenbelt into these lands?

6. From your perspective what would be the appropriate use for the lands within the "whitebelt"? 